$$
\text { vै }
$$




\title{
Visibility of Archaeological Record on the Surface
}

\author{
Luka Gruškovnjak
}

DOI:10.17234/9789531757799.5

\author{
Department of Archaeology \\ University of Ljubljana \\ Aškerčeva 2 \\ SI-1000 Ljubljana, Slovenia \\ luka.gruskovnjak@ff.uni-lj.si
}

When using archaeological surface survey method, be it for purposes of archaeological landscape research or archaeological resource evaluation, understanding visibility of archaeological record on the surface and factors affecting it is of crucial importance. Surface visibility must always be considered on multiple levels and five of these can readily be defined: (1) Visibility determined by geomorphic, pedogenic and other post-depositional formation processes. (2) Visibility determined by the nature of the archaeological record. (3) Visibility determined by techniques and strategies of the survey method. (4) Visibility determined by surface and other environmental conditions during the survey. (5) Visibility determined by the human factor.

Without considering these levels and using methodological procedures designed to control their effects on survey accuracy, any analysis and interpretation of survey results is at risk of being seriously erroneous and invalid. Furthermore, we should always bear in mind that surface survey is only capable of detecting disturbed and exposed archaeological record in the landscape. We are thus always dealing with incomplete distributions which primarily speak about landscape taphonomy and its effects on preservation, visibility and integrity of archaeological record in the landscape.

\section{Introduction}

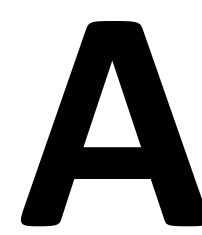
rchaeological surface survey is one of the principal methods of archaeological prospection and research on a regional level, but despite the long development of this method its capabilities and limitations are still often not well understood, especially its effectiveness as a discovery method (see for e.g. Ammerman 1981: 81-82; Wandsnider and Camilli 1992; Burger et al. 2004; Burger et al. 2008: 216-218, 228). This is a problem in any archaeological landscape and settlement research but it comes to the forefront especially when the survey is used as a tool for evaluating the presence of ar- chaeological resources before large-scale development projects. In such cases survey results may be the basis for decision making about the presence or absence of archaeological resources, needs for their protection and management, needs for excavation and in this case also for determining the size, time and cost of excavations (see Hey and Lacey 2001; Hey 2006; Medlycott 2017). In such cases, it is crucial that survey procedures are precise, reliable and accurate and that decisions based on their results are valid (see Banning et al. 2017: 468). But standard survey procedures generally do not allow for a realistic evaluation of the precision, reliability and 
accuracy of survey results or simply addressing the key question of »How much did we miss?« (Wandsnider and Camilli 1992; Burger et al. 2004). In tackling this problem, it is crucial to take into account the visibility of archaeological record on the surface and all variables affecting the discovery and recovery rate of the cultural material.

\section{Multiple levels determining visibility}

Visibility is generally accepted as an important aspect of archaeological surveys, which must be considered in the analysis and interpretation of survey results. In most surveys, however, dealing with visibility is mostly limited to documenting the amount of exposed ground surface or amount of vegetation cover in the field during survey and then using this information in the analysis to correct the raw data (e.g. Cherry et al. 1991: 27-28; Gaffney et al. 1991: 61; Terrenato 1996: 223; Terrenato 2000: 60, 66). However, the problem of visibility is much more complex and should be considered both in survey design and in the analysis of survey results on multiple levels:

(1) Visibility determined by geomorphic, pedogenic and other post-depositional formation processes.

(2) Visibility determined by the nature of the archaeological record.

(3) Visibility determined by techniques and strategies of the survey method.

(4) Visibility determined by surface and other environmental conditions during the survey.

(5) Visibility determined by the human factor.

Within each of these levels, a multitude of factors operate to influence surface visibility and detectability of archaeological record on the surface and consequently survey precision, reliability and accuracy by introducing biases into survey results. In the following text, each of these levels is defined and briefly explored by using information from a selection of relevant literature dealing with factors operating on the levels as they are defined in this paper $^{1}$. For each level, an example of a study demonstrating the importance of some of these factors is presented as well as some methodological solutions, proposed so far by different authors, for dealing with problems these levels present for survey archaeology.

1 The five levels have already been briefly defined and touched upon in Gruškovnjak 2017a. In the present paper considerations on some of these levels have been expanded, especially in the case of the 1st and 5th level.

\section{$1^{\text {st }}$ level determining visibility: geomorphic, pedogenic and other post-depositional processes}

On the first level visibility is determined by post-depositional formation processes affecting visibility, preservation, and integrity of the archaeological record. After cultural materials leave the systemic context, in which they were used, through different ways of deposition they enter the archaeological record and are affected by post-depositional processes. These include natural and anthropogenic processes that burry or expose them, move or transport them as well as degrade or destroy them (Fig. 1) (Schiffer 1972; Schiffer 1973: 25-30, 53, 6365; Schiffer 1983: 677; Sullivan 1978; Foley 1981: fig. 6.5; Butzer 1982: 98-122; Barton et al. 2002: 155-156, 166167; Burger et al. 2008: 205-211; Ozán 2017).

Among the key factors to consider regarding surface visibility and use of surface survey as a discovery, method are geomorphic and pedogenic processes which burry or expose the land surface and alter the soil profile. As no land surface is stable in the long run three basic scenarios must always be considered. First, erosion may slowly or rapidly remove material, lowering the surface through time $^{2}$. If the soil or sediment contains coarse fragments, natural or archaeological, the surface may eventually become enriched with them as a lag concentrate or carpetolith. Second, the surface can receive additions of mineral material which may be slow, steady or intermittent, as well as rapid and catastrophic. Slow additions of sediment aggrade the surface, eventually causing the soil profile to thicken. These processes, in soil science known as cumulization ${ }^{3}$ and developmental upbuilding ${ }^{4}$, are caused by eolian, hydrologic or human-induced additions of mineral particles to the soil surface. These often occur on alluvial surfaces, e.g. floodplains, in sediment receiving areas, e.g. colluvium or slopewash at the base of slopes or in micro-topographical lows, but it may also occur in the uplands. Catastrophic additions, as with floods or mass movements, may rapidly and deeply bury the surface, isolating it completely and causing retardant upbuilding (Johnson 1993: 76, figs. 8-10; Schaetzl and Anderson 2005: 169, 172, 456-460, 532-534, 543). Third, the processes of burial and erosion are always accompanied by a force vector which may move and transport

2 Soil profile characterized by lack of pronounced horizons (Peacock and Fant 2002: 97).

3 Soil profile characterized by an overthickened A horizon (Schaetzl and Anderson 2005: 458-459).

4 Soil profile characterized by an overthickened B horizon (Schaetzl and Anderson 2005: 458)

5 Soil profile characterized by relict $A$ and $B$ horizons or paleosol and a newly forming soil on top of the younger sediment (Schaetzl and Anderson 2005: 459). 


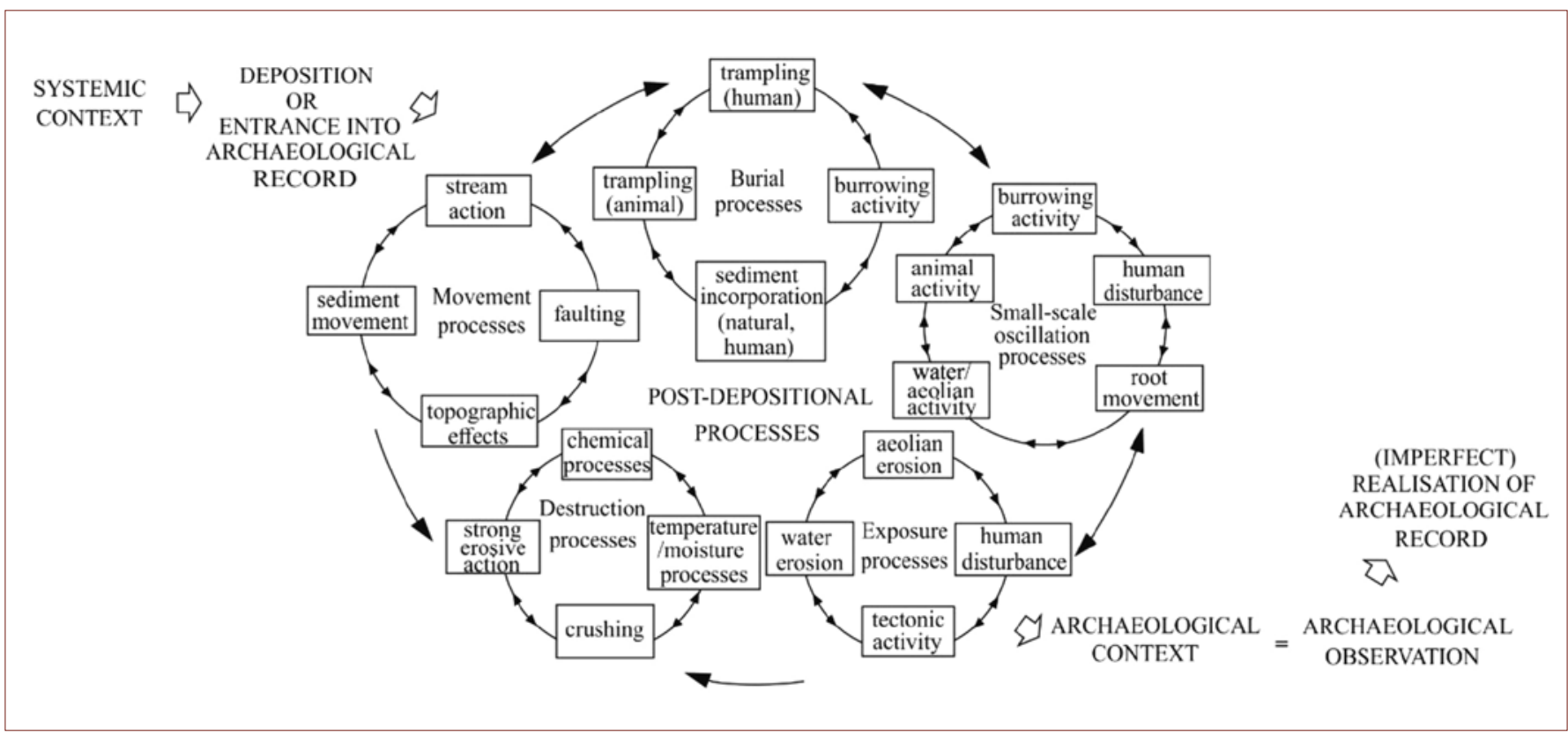

FIGURE 1. Scheme of post-depositional natural and cultural formation processes (Source: altered after Foley 1981b: fig. 6.5; also see Gruškovnjak 2017a: fig. 4).

surface materials. That is why soil scientists often realize that the process of burial alone simultaneously erodes the upper soil horizons, often leaving only B horizon as the only proof of soil surface existence prior to burial (Foley 1981: 170; Butzer 1982: 100; Schaetzl and Anderson 2005: 50). Thus, on a buried or exposed land surfaces, movement and transport of archaeological artefacts on the surface must be taken into account, as well as their incorporation into and movement with the burying or eroding sediment (e.g. Barton et al. 2002: 169-170). In any landscape we are surveying we must, therefore, be aware of what kind of geomorphological surfaces we are dealing with and what kind of debris flux, involving erosional and depositional processes, operated on them through the evolution of the landscape, especially during the Pleistocene and Holocene, up to the present day. Geomorphic surfaces can be erosional, constructive (aggrading) or a combination of both (see Schaetzl and Anderson 2005: 467, 471; also see Johnson 1993: 76; Van Nest 2002: 57, fig. 2).

Pedoturbation is another crucial, but rarely considered, factor affecting surface visibility as well as the nature of the stratified subsurface archaeological record. It is a ubiquitous and continuous process synonymous with soil mixing. From an archaeological perspective, pedoturbation is very important because it can result in burial of archaeological artefacts and architectural features even without the additions of mineral matter, as well as in sorting, mixing and moving of the larger size fractions of soil or sediment, like gravel, stone, and crucially archaeological artefacts ${ }^{6}$. Bioturbation, i.e. pedoturbation by soil fauna (faunalturbation) and plants (floralturbation), can, for example, cause surface aggradation and thus burial of archaeological record through surface mounding of fine soil fractions by animals. It can also cause a downward movement of coarse fragments via loosening and within-horizon jostling and undermining (by root growth and decay, and animal burrowing). This eventually causes settling of the coarse fraction at the maximum depth of burrowing and formation of so-called stone-lines and artefact-lines, or layers, overlain by a biomantle, i.e. a layer of material sorted and brought to the surface by animals ${ }^{7}$. With enough time elapsed the entire artefact size range archaeologists typically recover and study will be concentrated into a subsurface stone layer, only the smallest debris remaining mixed in the upper fine textured biomantle. Besides rendering archaeological record invisible on the surface through

6 For pedoturbation processes that can move coarse fragments and representative sources on the topic see Schaetzl and Anderson 2005: tab. 10.2

7 In such a case the principle of stratigraphic superposition does not apply as the stone line and biomantle are synchronous. Also a false impression of paleo land surface is created in this way, and in some cases the amount of displacement can be sufficient to alter stratigraphic relationships and may potentially cause significant errors in dating of archaeological features. However, if not enough time has elapsed for artefacts of different periods to reach the maximum depth of bioturbation, the relative stratigraphic relationships are preserved (Atkinson 1957: 222-224, 226; Johnson 1989: 383; Balek 2002: 46-48; Van Nest 2002: 77; Schaetzl and Anderson 2005: 242). 

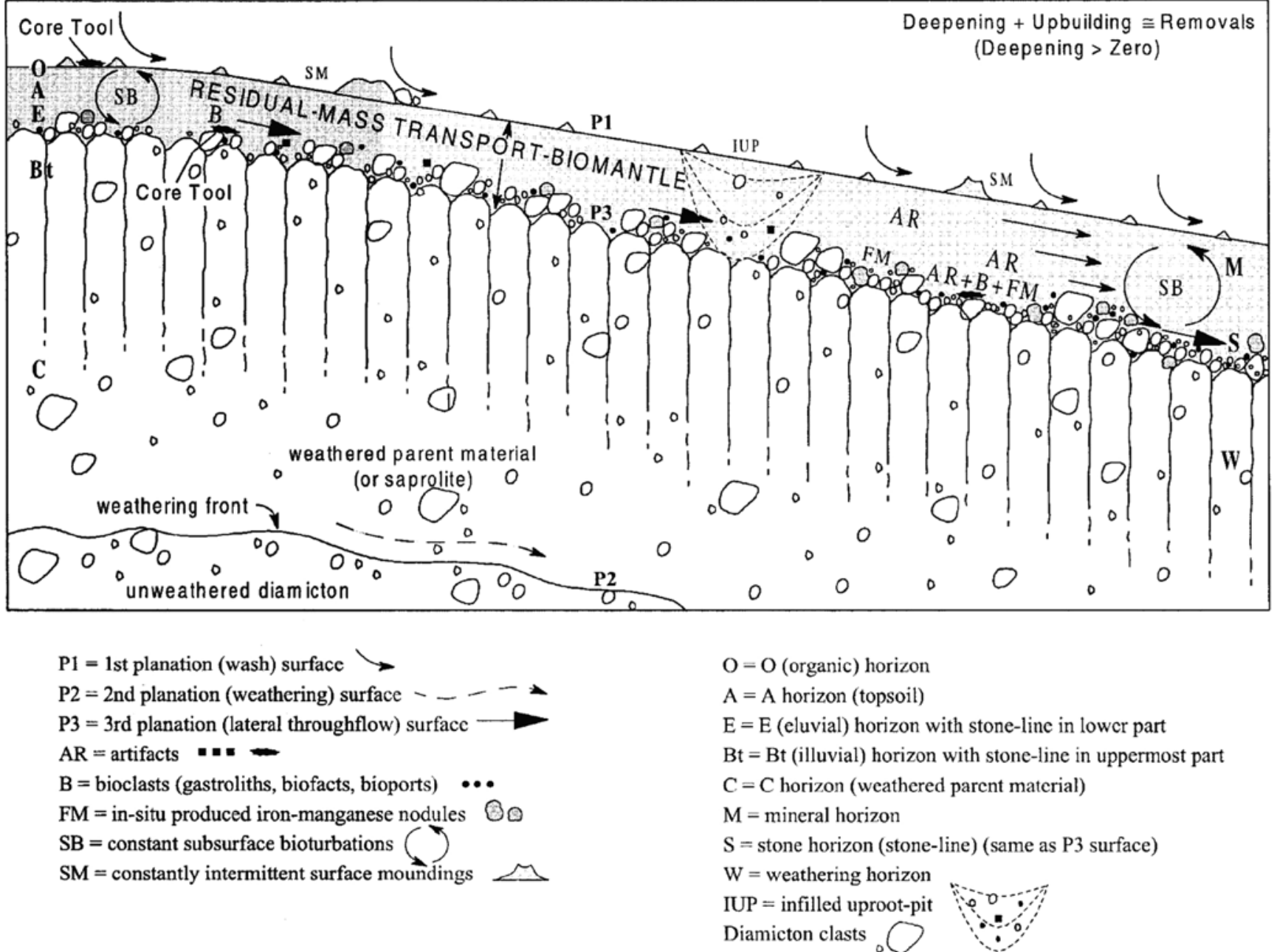

FIGURE 2. A Schematic example of dynamic denudation in landscapes underlain by stony diamicton or other sedimentary rock that contains relatively weathering-resistant clasts. The scheme portrays how small-scale slope processes operate on drift landscapes in the midcontinental United States and Europe. The legend identifies the symbols and processes. Only the major processes of the model are showcased, with a focus on the biomantle, which extends from the surface to the base of the stone-line. Material is removed as solutional and particulate matter from the soil-landscape system via $\mathrm{P}_{1}, \mathrm{P}_{2}$, and $\mathrm{P}_{3}$ planation surfaces. Due to bioturbation and gravity, artefacts, manuports, and bioclasts deposited on the surface gradually sink to the top of the stone-line ( $\mathrm{P}_{3}$ surface). The biomantle then slowly migrates downslope (migration rates depend on slope angle, intensity and duration of bioturbation, climate, etc.). Ferricrete and other metallic bodies may form in place and/or become incorporated into the stone-line from below as the landscape slowly downwastes. Soil deepening (D) is an active process in the figure (i.e, $D$ > zero), and both deepening and upbuilding $(U)$ approximate removals $(R)$ in the soil thickness $(T)$ relationship: $T=f(D+U-R)$. Consequently, the denudating $P 1$, $P 2$, and $\mathrm{P}_{3}$ planation surfaces gradually move downward as the landscape slowly downwastes (Source: Johnson 2002: 22,24 , fig. 2).

burial, the faunal activity may also seriously affect the reliability of surface-collection data by causing a disproportionate amount of small-sized artefacts (artefact size dependent on animal size) to be present on the surface, while large-sized artefacts are buried. Similar sites with differential amounts of faunal activity and different animal species involved in it may thus display very different contents in their surface assemblages. Also, because the biomantle slowly moves downslope (rates of mass transport vary spatially and temporally with local conditions), it is both sedentary in the short term and transported in the long term. In addition the stone-line often acts as a lateral aquifer or lateral subsurface throughflow zone on sloping surfaces and is thus subjected to aquaturbation, which mainly affects the fine soil fraction, but may potentially cause movement, abrasion, degradation etc. of artefacts in the stone-line (Atkinson 1957; Erlandson 1984; Bocek 1986; Johnson 1989; Johnson 1993: 72, 7476; Balek 2002; Johnson 2002; Peacock and Fant 2002; Van Nest 2002: 57, 59, 62-63, 77-79, figs. 2-4; Schaetzl and Anderson 2005: 239-255, 543-546, tab.10.1-2; Araujo 2013; Ozán 2017: 2-4). 
Other forms of bioturbation can also bring larger clasts, including archaeological artefacts, to the surface. Tree uprooting, for example, is a major cause for this and as the fine materials are washed away, coarse fragments can become concentrated as a surface lag. Tree uprooting can move particles in any direction, bringing buried materials up as well as introducing surface materials to lower levels of the soil while soil horizons are disrupted and mixed together. Repeated uprooting results in so-called "natural ploughing" or "tree ploughing" and through long periods of time this localised and spatially discontinuous process may affect very large portions of the landscape, often creating the so-called cradle-andknoll or pit-and-mound micro-topography. Deep burrowers may also bring deeply buried materials into the near-surface environment, and larger burrowers such as rodents may cause considerable lateral movements of artefacts. Larger clasts can also be brought to the surface and sorted via cryoturbation (freeze-thaw processes) and argilliturbation (Bocek 1986; Johnson 1993: 74; Balek 2002: 42-48; Johnson 2002: 8-9; Peacock and Fant 2002: 91-92; Van Nest 2002: 57; Schaetzl and Anderson 2005: 243-244, 259-262, 501; Pawlik 2013).

Thus, it must be realized that biomechanical processes of soil formation are inherent to all soils and that archaeological contexts, be it in the bottomlands or uplands, have been universally altered by biomechanical processes. Case-by-case assessments of the formation processes affecting sites are required to discern which patterns can be attributed to human activities and witch to other processes, though this task is inescapably complicated by equifinality (Van Nest 2002: 78; Burger et al. 2008: 205; Ozán 2017: 12-13).

The above-mentioned processes are only a part of the dynamic denudation model (Fig. 2) developed by Donald Johnson (1993; 2002) ${ }^{8}$, which must be considered in any archaeological landscape survey, analysis and interpretation. As summarized by Johnson (1993: 7677): "Dynamic denudation theory provides a rational explanation for the evolution of tropical, subtropical and temperate landscapes with three-tiered soils that may or may not bear stone-lines. The dynamic processes and conditions are driven by gravity, water and biotic agents. The framework is a synthesis of tripleplanation, soil evolution, biomantle, soil thickness, etchplanation, and mass transport theory fused with /.../ A, E, B, C soil horizon designations, and hydrological principles of lateral throughflow. /.../. It explains soil-slope systems with or without stone-lines in a variety of landscapes underlain

8 For historical background and comments see Schaetzl and Anderson 2005: 324-338, 537-546. by variable rock types, including those that are saprolitized. Dynamic denudation principles should have wide applications in archaeology, ecology, forestry, geomorphology, mineral exploration, and pedology."

A case study of archaeological record's surface visibility considering dynamic denudation principles is provided in western Illinois, U.S.A., by J. Van Nest (2002). Among archaeologists working in this area the prevailing view has been that before a late prehistoric establishment of bison into the region, Illinois prairies were mostly uninhabited. Seemingly confirming this view was the scarcity of surface archaeological materials away from the river valleys. Surface surveys of upland terrain in the region discovered only ribbon-like distributions of sites on the slope shoulders and upper backslopes along headwater valleys. For a long time, it has been presumed that during the Holocene the uplands underwent massive hillslope erosion, causing nearly all archaeological materials to became lag deposits, which are now incorporated into historic plough zones and are thus all visible on the surface. However, Van Nest observed that erosion in western Illinois uplands is spatially restricted and that no massive hillslope erosion occurred during the Holocene. Large areas of this landscape retain soil profiles with biomantles and buried archaeological remains. She examined the interaction of biomantle-stone zone formation, soil creep on a hillslope transect (catena) and processes related to vegetation type (forest vs. prairie) (Fig. 3). At the hilltops where soil loss by creep is effectively zero, large artefacts have been readily buried by soil fauna to depths below the plough zone. On the contrary, backslope positions are so steep that the rate of soil creep exceeds the rate of artefact burial by soil fauna and thus they remain at the surface. At intermediate slope steepness positions on slope shoulders, burial by soil fauna is rapid enough for the artefacts to start sinking, but erosion is also rapid enough to allow only shallow burial. Thus, artefacts are protected from surface disturbances but may be incorporated into the historic plough zone. At the bases of slopes, artefacts may be buried by sediment washed from upslope, or by alluvium (Fig. 3A). Besides the position on the hillslope transect, vegetation also proved to be an important factor in soil development and artefact burial. Tree ploughing in forests can overwhelm the downward movement of artefacts by soil fauna and in addition, the organic-rich layer with soil fauna activity of many forest soils is so thin that it is now entirely incorporated into historic plough zones. Contrary, in prairie soils the organic-rich A horizons extend to considerable depths and artefacts become buried in biomantles below the depth of ploughing (Fig. 3B). There is probably also a link between prehistoric Indian 
vegetation burning practices and the position of the forest-prairie boundary on upper slopes, and consequently the distribution of surface and buried habitation scatters in this landscape. The process of burial by soil fauna has been documented for Archaic period sites (>3500 B.P.), while not enough time has elapsed for Woodland period (<2500 B.P.) artefacts to become buried to sub-plough zone depths. Thus, the once prevailing assumption that upper slopes along valleys are an eroded, degraded landscape where all cultural remains occur at the surface, in the plough zone, or occasionally in pits reaching below the plough zone is now obsolete. The biomantle-stone zone hypothesis now predicts that almost all pre-Woodland sites occurring across the upland prairie regions will be buried and consequently not detectable by surface surveys (Van Nest 2002: 79-83, figs. 8-9; Schaetzl and Anderson 2005: 254).

This case study clearly demonstrates that consideration of pedogenic and geomorphic processes along a catena is crucial for decision making about which prospection method is appropriate for a particular surface while any analysis and interpretation of survey results as well as settlement and land use patterns, which does not consider these, cannot be regarded as valid (see e.g. Bettis and Mandel 2002: 141-142, 149-152; Peacock and Fant 2002: 92, 95; Burger et al. 2008: 205-211; Banning et al. 2017: 469; Ozán 2017). For example, the surface survey will be pointless in a deeply buried landscape where the subsurface survey is called for instead, and no surface finds in such a case do not mean that there is no subsurface archaeological record present in the area (see e.g. Brookes et al. 1982; Stafford and Creasman 2002). Only archaeological record affected by exposure or disturbance processes might be expected to be visible on the surface, while buried sites will not be. Finds might also be dispersed or even drastically moved by post-depositional processes and the location of finds in a colluvium, for example, may be far removed from the location of their primary deposition and incorrectly interpreted if colluviation process is not identified (e.g. Foley 1981: 166-174; Butzer 1982: 98, 100-117; Ebert et al. 1987: 165-166; Burger et al. 2008: 221-227).

Often overlooked, however, is that the patterning of these natural processes, which affect the visibility, preservation and integrity of the archaeological record, are of a very local nature. They are controlled by local microtopography and other small-scale factors and are thus often of an even smaller scale than might be assumed to fall within the boundaries of culturally-caused clusters of artefacts, or sites. Consequently the existing regional scale maps and data on these processes in any given area are usually too general and not precise enough for archaeological purposes which is why all survey projects should incorporate localized small-scale soil geomorphological ${ }^{9}$ mapping and other geoarchaeological methods into the initial (and if necessary subsequent) phases of their survey design (Ebert et al. 1987: 173; Stafford and Creasman 2002: 120-121; Johnson 2002: 11; Schaetzl and Anderson 2005: 501-506; Ozán 2017: 2, 7, 12, 13).

In the context of burial an exposure processes it must be mentioned that globally speaking in temperate zones, most of the surfaces are generally affected by constant aggradation and consequently most of the archaeological record is buried, thus displaying very low artefact densities and poor visibility on the surface, while in arid zones most of it is exposed, thus displaying much higher artefact densities (lag concentrate) and better visibility on the surface (Bintliff and Snodgrass 1988: 508-512, fig. 2 ). That is why the surface survey in temperate zones is almost exclusively applied to ploughed surfaces, where subsurface materials are potentially being brought to the surface. Mechanical ploughing as a form of pedoturbation or anthropoturbation can be considered as a largescale formation process unique to modern surfaces. Though more severe its effects are similar as in the case of many other natural and anthropogenic pedoturbation processes. Also similar are factors affecting it, but their effects are drastically increased. When studying archaeological record in the plough-zone we must consider at least (1) lateral displacement and its effect on spatial patterning; (2) vertical displacement or the circulation of finds in the plough-zone and the functioning of the surface as a sampling process determining the relation between the whole population of finds in the ploughzone and artefacts brought to the surface; (3) changes in state of preservation of various classes of material in specific conditions; (4) duration, direction and depth of ploughing as well as ploughing equipment; and (5) local characteristics of soil, relief and post-depositional burial of the archaeological record. (see Lewarch 1979; Jermann 1981; Lewarch and O'Brien 1981a: 308; Lewarch and O'Brien 1981b; Ammerman 1985: 34-35; Odell and Cowan 1987; Reynolds 1988; Boismier 1989; Yorston et al. 1990; Dunell and Simek 1995; Schaetzl and Anderson 2005: 292-293). Various experimental studies have shown that what we see on the ploughed surface is only the tip of the iceberg and a random one at that (Ammerman 1985: 37, 39).

9 Soil geomorphology can be defined as the study of soils and their use in evaluating landform evolution, age and stability, surface processes and past climates. It can also be more broadly defined as the study of the origin, distribution end evolution of soils, landscapes and surficial deposits and the processes that create and alter them (Schaetzl and Anderson 2005: 465). 
FIGURE 3. (A) A slope transect model showing where buried and surface-exposed archaeological remains are expected in the western Illinois uplands.

(B) Influence of soil type on the expected depth of stone-lines in fully formed faunalmantles of western Illinois (Source: Van Nest 2002: figs. 8-9).
A

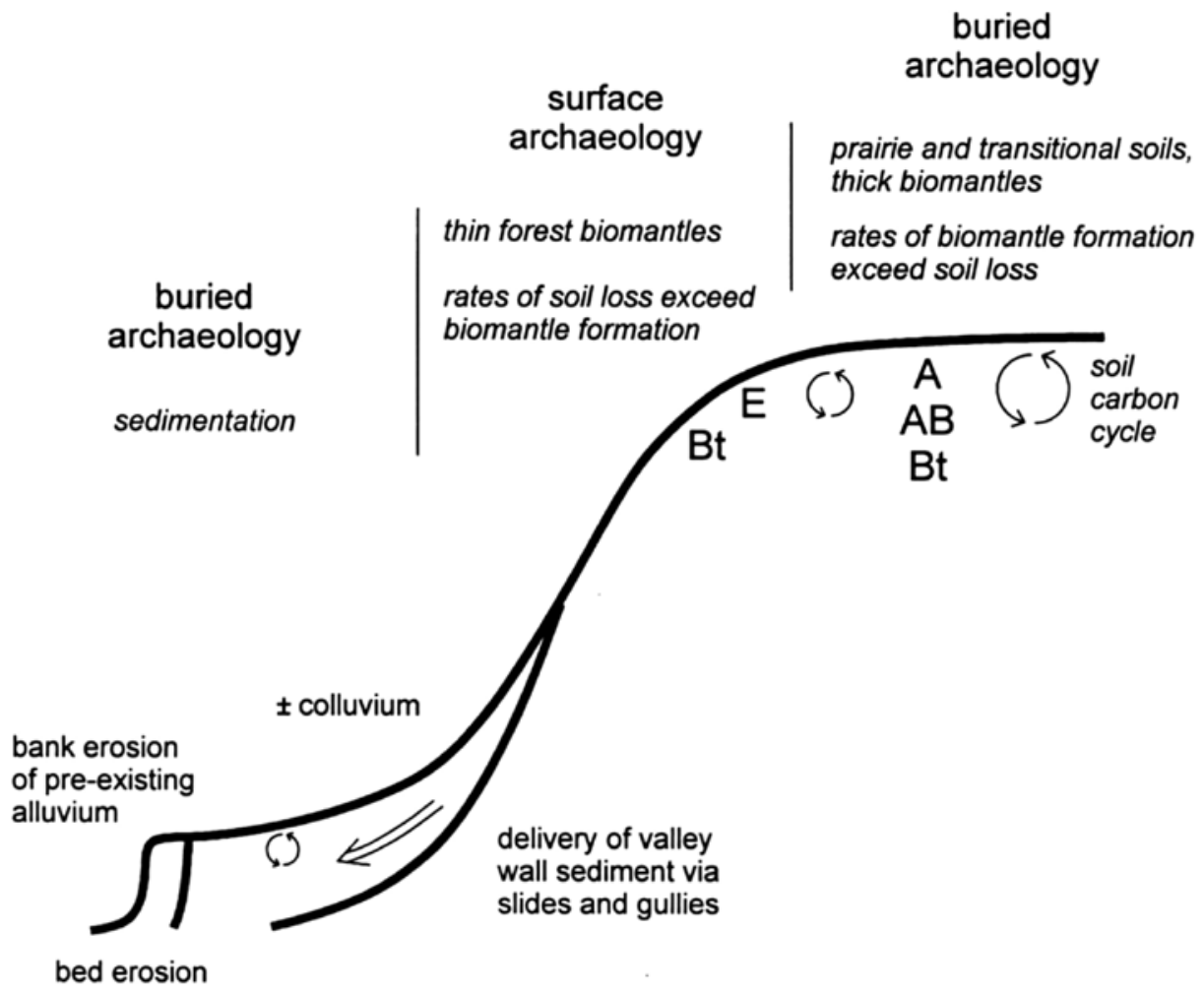

B

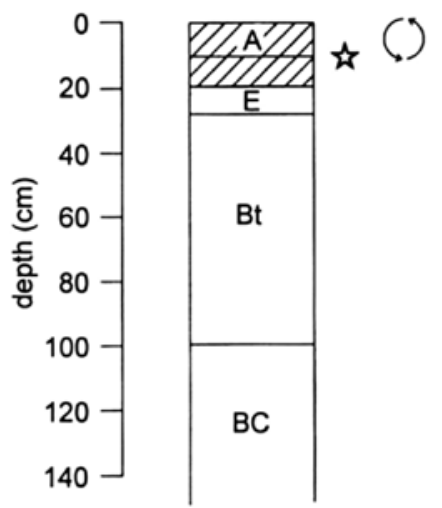

prairie-to-forest

transitional soils

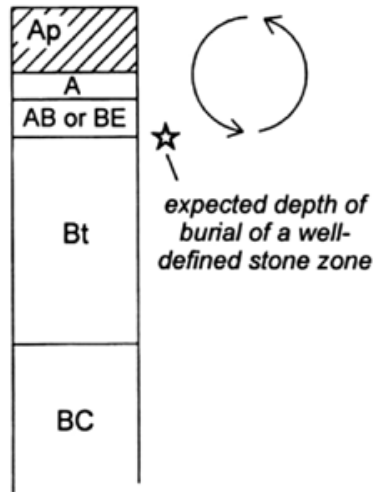

prairie soils

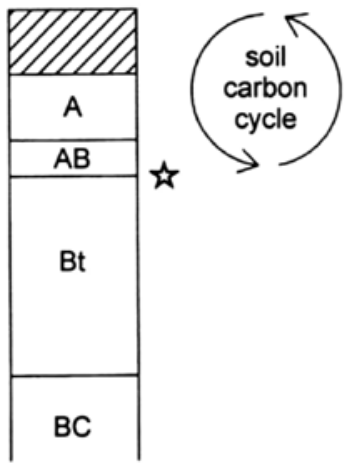

$2^{\text {nd }}$ level determining visibility: nature of the archaeological record

On the second level, visibility is determined by the nature of the archaeological record itself. Among key factors here, are obtrusiveness, clustering and density of artefacts (Schiffer et al. 1978; Wandsnider and Camilli 1992; Banning et al. 2017: 472-473).
Obtrusiveness of artefacts is conditioned especially by their size, shape and colour as well as by the relationship of these properties to the natural material of the soil surface. More the archaeological material differs from the natural background noise of the soil matrix more obtrusive it is. This means that the effect of artefact properties is specific to specific circumstances and must always be evaluated in light of local conditions. Generally as the 
size of the artefact increases so too does its obtrusiveness, but there are variations in this relation conditioned by local circumstances. For example, if pebble stones of intermediate size class are predominating, intermediately sized artefacts might be less obtrusive than small sized artefacts. Also, the more the artefact's shape differs from the shapes of the natural material in the background, more obtrusive it will be and so in some circumstances small unnaturally shaped artefacts will be more obtrusive than larger more naturally shaped artefacts. Similarly, in soils of different colours and in the presence of natural stones of different colours differently coloured artefacts will contrast the natural background differently and will thus have different obtrusiveness. Thus, in different natural backgrounds artefacts of different sizes, shapes and colours will have different levels of obtrusiveness. That is why the natural matrix and any changes or variations in it during the survey should be described in detail in order to evaluate the effect of artefact obtrusiveness and biases it incorporates into survey results (Wandsnider and Camilli 1992: 174, 176, 177-179; see also Banning et al. 2006: 726, 732; Banning et al. 2010).

Artefact clustering and density also affect the recovery rate during the survey. More clustered than isolated artefacts will be discovered and the higher the density of the cluster the higher percentage of artefacts present in it will be discovered. The interaction between clustering, density and obtrusiveness is very important but it is not simple and straightforward. Obtrusiveness will especially affect the differential artefact recovery at low densities while its effect at higher densities will be lower. In this case, the size of the artefacts plays the most important role for large artefacts are quite consistently recovered at high as well as low densities while small artefacts are mostly recovered in cases of higher densities (Wandsnider and Camilli 1992: 174, 180-182).

Besides the effects post-depositional processes ( $1^{\text {st }}$ level determining visibility) have on artefact surface density, artefact density is also conditioned with the duration of the past occupation or activity, the intensity of activities involving discard behaviour, focus of such activities to a specific location and integration of durable cultural materials into these activities, such as stone and pottery, while discovery of other types of activities is severely limited. Similar factors also apply to periods for we are more likely to discover remains of periods characterised by locally concentrated long-lasting activities or occupation, higher population densities and production of durable cultural materials, which are more resistant to destruction. Regarding preservation, time or progressive degradation and destruction of materials also plays a role, as well as types of soil, which have different effects on the degradation and destruction of cultural materials. However, visibility is also conditioned by the resolution of our dating or relative archaeological visibility, meaning that periods with highly diagnostic material will have higher visibility in surface assemblages than periods with less diagnostic material, and if finds from a particular period are not recognised it will stay invisible even though present in the collected material (see Hope-Simpson 1984: 116; Bintliff and Snodgrass 1985: 138; Gallant 1986: 415; Schofield 1989: 460-462, 466468; Barker 1996: 167; Bintliff 2000: 205-206, 212-213; Banning 2002: 226; Novaković 2003: 145; Hey 2006; Vermeulen and Mlekuž 2012: 209).

For dealing with problems of artefact obtrusiveness, clustering and density, incorporation of seeding experiments into survey design has been proposed as a way to enable the evaluation of biases incorporated into survey results by these properties of the archaeological record (Wandsnider and Camilli 1992: 183, 185). Such an experiment would be done on a smaller plot or plots of the survey area, representative of the local conditions, by seeding a known quantity of non-archaeological artefacts and mapping their distribution in order to control the most relevant attributes such as colour, shape and size of artefacts as well as different degrees of their clustering and density. These experimental plots would be surveyed using the same procedure as throughout the survey area and the results would provide a quantitative measure for evaluating the effects of these characteristics on the recovery of archaeological artefacts in the specific circumstances of the survey area and with the specific procedure used in the survey project (e.g. Wandsnider and Camilli 1992: 173-176; also see Banning et al. 2017: 475-476).

An example is provided by the Seedskadee (Green River, Wyoming, U.S.A.) seeding experiment, presented by L. Wandsnoder and E. L. Camilli (1992), in which an intensive (5 $\mathrm{m}$ transect interval) distributional survey technique was used. With the distributional technique, discovery is done in two phases, first systematically by the discovery crew, and then unsystematically by the encoding crew. Regarding shape and colour of seeded artefacts (washer and nails of black and buff colour) more "unnaturaly" shaped washers (71\%) were recovered and slightly lower number of larger but less unnaturally shaped (stick-like) nails (61\%), while more black artefacts $(70 \%)$, which were more contrasted with the soil surface, were recovered than buff artefacts (62\%). Regarding isolated vs. clustered seeded artefacts the discovery crew recovered $10 \%$ of all isolated and $69 \%$ of all clustered artefacts, while the encoding crew recovered additional $6 \%$ of all isolated and $12 \%$ of all clustered artefacts. In total, 
FIGURE 4. Seedskadee seeding experiment results.

(A) Frequency and percentage of recovered seeded artefacts by characteristics.

(B) Percentage of orangeflagged (recovered by discovery crew) artefacts vs. cluster density.

"Buff" - clusters with buff washers and nails;

"Black" - black washers and nails;

"Mixed" - buff and black washers and nails;

"Nails" - buff and black nails;

"Washers" - buff and

black washers

(Source: Wandsnider and Camilli 1992: tab. 1, fig. 2).
A

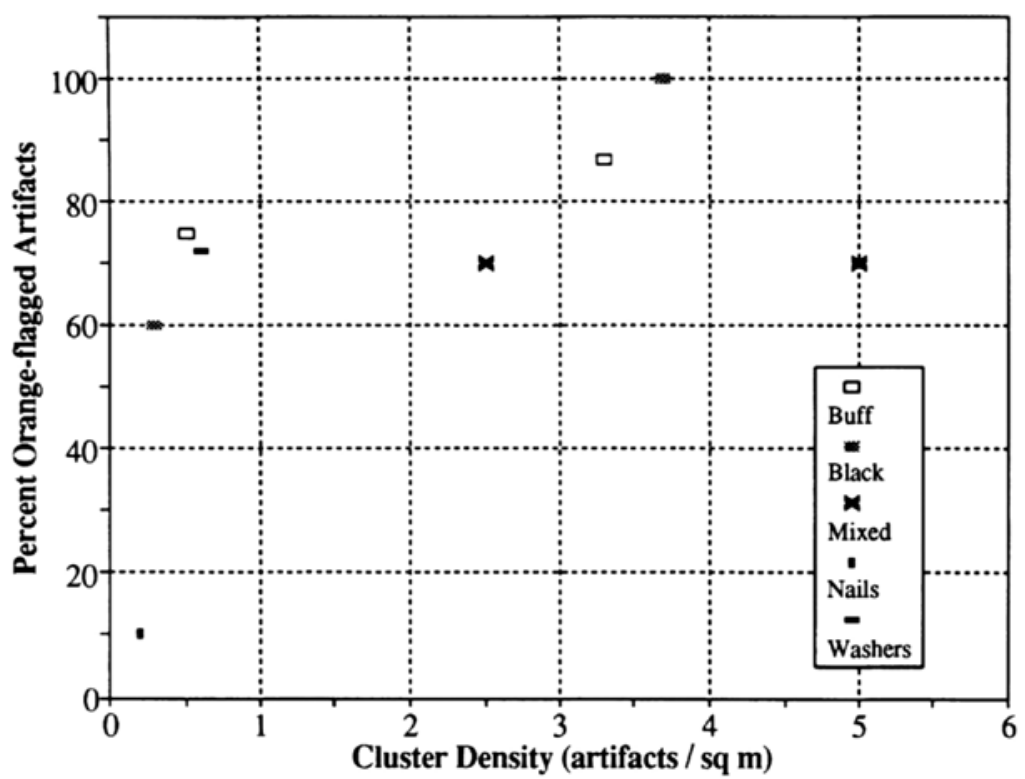

B

\begin{tabular}{|c|c|c|c|c|c|c|c|}
\hline \multirow{3}{*}{$\begin{array}{l}\text { Secded } \\
\text { artifacts }\end{array}$} & & \multicolumn{4}{|c|}{ Recovery } & & \\
\hline & & \multicolumn{2}{|c|}{$\begin{array}{c}\text { Discovery } \\
\text { crew }\end{array}$} & \multicolumn{2}{|c|}{$\begin{array}{c}\text { Encoding } \\
\text { crew }\end{array}$} & \multicolumn{2}{|c|}{ Total } \\
\hline & & No. & $\%$ & No. & $\%$ & No. & $\%$ \\
\hline \multicolumn{8}{|l|}{$\begin{array}{l}\text { Isolated } \\
\text { Buff }\end{array}$} \\
\hline Nails & 12 & 0 & 0 & 0 & 0 & 0 & 0 \\
\hline Washers & 12 & 1 & 8 & 1 & 8 & 2 & 17 \\
\hline \multicolumn{8}{|l|}{ Black } \\
\hline Nails & 12 & 2 & 17 & 0 & 0 & 2 & 17 \\
\hline Washers & 13 & 2 & 15 & 2 & 15 & 4 & 31 \\
\hline Total & 49 & 5 & 10 & 3 & 6 & 8 & 16 \\
\hline \multicolumn{8}{|l|}{ Clustered } \\
\hline Nails & 44 & 29 & 66 & 3 & 7 & 32 & 73 \\
\hline Washers & 35 & 29 & 83 & 1 & 3 & 30 & 86 \\
\hline \multicolumn{8}{|l|}{ Black } \\
\hline Nails & 27 & 15 & 56 & 8 & 30 & 23 & 85 \\
\hline Washers & 48 & 34 & 71 & 7 & 15 & 41 & 85 \\
\hline Total & 154 & 107 & 69 & 19 & 12 & 126 & 82 \\
\hline Grand total & 203 & 112 & 55 & 22 & 11 & 134 & 66 \\
\hline
\end{tabular}

dramatically more clustered (82\%) than isolated (16\%) artefacts were recovered, with the inspection of $20-40 \%$ of the ground surface ( $5 \mathrm{~m}$ transect intervals and inspection of 1-2 m transect strips) (Fig. 4A). Also, as the cluster density increased, so did the percentage of total seeded artefacts discovered in the cluster (Fig. 4B). Furthermore, of all the isolated seeded artefacts discovered (systematically and unsystematically) the discovery crew recovered $62.5 \%$ and the encoding crew $37.5 \%$ as opposed to clustered artefacts, the majority of which were recovered by the discovery crew (85\%) as compared with the encoding crew (15\%) (Fig. 4A). This observation has important implications especially regarding the discovery rate of clustered and unclustered surface distributions by standard survey procedures with only one (systematic) discovery phase (Wandsnider and Camilli 1992: 174, fig. 2, tab. 1).

Because of two discovery phases, the distributional survey technique also allows some evaluation of recovery rates in the case of archaeological distributions, where total quantity and distributional pattern of the sampling universe are not known (Wandsnider and Camilli 1992: 
176). With standard survey procedures, where discovery is done only in one phase, this is not possible and only seeding experiments incorporated into survey design would allow evaluation of artefact obtrusiveness, clustering and density. In the case of standard surveys with transects in $15 \mathrm{~m}$ intervals, a lot of the same high-density clusters might be discovered as with the more intensive distributional survey. However, because only $6-13 \%$ of the ground surface is inspected, presuming that only 1-2 $m$ away from the transect lines are inspected, this allows for only $6-13 \%$ of surface artefacts to be recovered. But because of the biases incorporated by all levels determining visibility only part of these $6-13 \%$ will be discovered and the fraction will be different for different areas, different types of artefacts, different collectors etc. This means that the fraction of the sample remains unknown and that such techniques themselves support the apparent "sitedness" of archaeological record or the perception that archaeological record mainly consists of rare high-density distributions or sites and just a few isolated artefacts. From this point of view, such a survey procedure is neither an off-site survey, neither a full/ total-coverage survey. The population of isolated phenomena is at least 8-17 times greater than discovered by such surveys, but these are already problems related to the $3^{\text {rd }}$ level determining visibility discussed below. Also, observations that very low-density archaeological distributions are comprised mostly of larger artefacts may reflect discovery bias owing to effects of interaction between differential artefact obtrusiveness, clustering and density, rather than differential use and discard. Furthermore, the results of such seeding experiments clearly show that even very intensive surveys fail to provide accurate and reliable results, especially in low-density areas, pointing to the dangerous business of interpreting survey results, especially with the help of quantitative analyses, when measures to quantitatively evaluate the effects of discovery biases are not incorporated into survey design (Ibid.: 182-185).

Until now, we have only considered those properties of the nature of the archaeological record, connected with artefacts, for these represent the basic units of observation in the surface survey. Artefacts alone, however, cannot be a sufficient criterion for discovering the presence and for determining characteristics of the archaeological record, considering that it constitutes of (1) artefacts, (2) features, (3) anthropogenic soil horizons, (4) organic materials, and (5) chemical and geophysical anomalies. In different types of sites or remains, these constituents are present in different ratios (McManamon 1984: 226228). With the surface survey, we are detecting only artefacts and rarely features, and therefore, by detecting only one or rarely two types of constituents, the surface survey is an inherently biased discovery method. That is why the use of multiple survey methods, each detecting a different kind of archaeological remains or constituents of archaeological record are called for, at least if our intention is to discover various types of archaeological remains in the landscape and not only large high-density distributions of artefacts. It is not possible to blindly rely on the presuppositions that high densities of surface artefacts correspond to high densities of subsurface artefacts and features as well as areas of most intensive past human activities. Many studies show that surface distributions do not or only partly reflect subsurface distributions, that important sites with large number of features may contain very low numbers of subsurface artefacts and even less surface artefacts, as well as that many sites manifest themselves on the surface with lower densities than off-site distributions and therefore cannot be quantitatively recognized (Shott 1987: 361-362; Schofield 1989; Bankoff et al. 1989: 70-72; Bintliff 1996: 252; Bintliff 2000: 206-209, 212; Fentress 2000: 48-49; Hey and Lacey 2001; Medlycott 2017).

\section{$3^{\text {rd }}$ level determining visibility: techniques and strategies of the survey method}

Visibility is also determined by the techniques and strategies of the survey method. Here term method is understood as the basic method such as surface survey, subsurface survey, geophysical survey etc., while the technique determines the basic procedures used such as systematic fieldwalking or surface collection (e.g. Cherry et al. 1991), distributional survey (e.g. Ebert et al. 1987), point-sampling (e.g. van de Velde 2001), probability survey (e.g. Plog 1976) etc. in the case of surface survey method. Strategy refers to survey intensity and the shape, size and spatial layout of the survey grid and/or collection units used (e.g. transects, quadrats), or in the case of probability survey to a simple random, stratified random, systematic or stratified systematic unaligned sampling strategy used ${ }^{10}$.

Generally, the more intensive the survey and slower the pace, more surface material will be discovered (e.g. Wandsnider and Camilli 1992: 177, 183, fig. 3; Banning et al. 2006; 2010; 2011; but see below). For example,

10 This distinction between method, technique and strategy is adopted after Elco Rensink's presentation of the Best Practices Prospectie project at the Finds in the Landscape. New Perspectives and Results from Archaeological Surveys. / Funde in der Landschaft. Neue Perspektiven und Ergebnisse archäologischer Prospektion international conference, held on June 12th-13th at the Fritz Thyssen Stiftung in Cologne, Germany. Results of the project achieved so far are accessible at www.archeologieinnederland.nl (see Gruškovnjak 2017b). 
when using transects recovery will be primarily determined by transect intervals, which will determine the size of phaenomena the survey is capable of discovering. Phaenomena smaller than the transect interval will thus be discovered only due to coincidence (e.g. Cherry et al. 1991: 18-20). The capability of different shapes and sizes of aggregate units and their layout to discover sites according to their size and artefact density can be calculated by mathematical formulas based on search theory or recovery theory (e.g. Miller 1989; Sundstorm 1993). However, these must generally presume that if the aggregate unit intersects the area of a certain phenomenon it will be discovered, though the reality is not as simple. The chance of discovery is also determined by all other factors of all of the five levels determining visibility and all of these cannot be taken into account in such calculations, which is why they are only capable of evaluating the effectiveness of discovery in ideal circumstances. Besides, such calculations are mostly limited to evaluation of discovery capability for discrete distributions, i.e. sites, and not off-site distributions.

Because of the great variability in the surface visibility of archaeological record in the landscape, each survey area should be stratified into zones according to visibility (Banning et al. 2006: 740; Banning et al. 2017: 469). That is according to visibility as determined by the first and fourth level, as well as second level in case its properties are already known to a certain degree. For each zone, method, technique and strategy of a survey that will perform best in the given conditions should be determined $^{11}$, while most surveys use a standardized procedure throughout the survey area despite the differences in visibility. This difference is related to two different approaches to survey which are connected with the problem of data comparability, views on which differ among survey archaeologists. The core of this problem is in the question whether survey results of a certain area are comparable if the same standardized procedure was used throughout, or are they comparable if the same chance of discovery was assured by using different procedures according to different visibility conditions? Here, the latter approach is being emphasised.

Furthermore, the capability of addressing the question "What did we miss?" is generally absent in most surveys and therefore their effectiveness cannot be realistically evaluated (Burger et al. 2004: 411). For tackling with this problem to a certain degree, the proposition of using control seeding experiments has already been mentioned, while intensive resurveys of certain control

11 This is a point also emphasised in the Best Practices Prospectie project (see f.n. 10). areas through property-based investigations would be yet another or additional option which would allow for comparison of recovery rates with the standard procedure used in the survey project. Regarding the definition of a property-based approach, we may follow Burger et al. (2004) who differentiate archaeological surface survey procedures according to their numerous goals. Discovery-based surveys identify geographical aspects of the surface record by locating and describing clusters of artefacts, while property-based approach focuses on evaluating the accuracy of technique and strategy used as well as on formational aspects of the regional record. A property-based approach will, therefore, be especially valuable in cases of geomorphologically active and topographically diverse landscapes (Ibid.: 410; also see Banning et al. 2017: 474-476).

An example of such a property-based investigation is provided by Burger et al. (2004) with the experiments performed in the Oglala National Grassland (Nebraska, U.S.A.), where the multi-scale Modified-Whittaker sampling plot $^{12}$ (Figs. 5-6) borrowed from plant ecology was used and surveyed at different intensities. The main technique used was a distributional survey in 70 cm intervals, followed by a resurvey of smaller control areas with crawl survey (the fieldworkers inspected the surface by crawling on their knees shoulder by shoulder). In 14 experiments done in this way it was discovered that the crawling survey recovered from $170 \%$ to $1000 \%$, or on average $350 \%$, more artefacts than the walking survey in $70 \mathrm{~cm}$ intervals, which was in itself already absurdly intensive if compared to more standard survey procedures done in 10-15 $\mathrm{m}$ intervals. These re-

12 Modified-Whittaker multiscale sampling plot (Fig. 5) has been developed for plant species surveys in landscape ecology and is devised in a way to enable data collection at spatial scales of 1,10 , 100 and $1000 \mathrm{~m}^{2}$. Former plant species survey procedures, which were very similar to archaeological systematic surface surveys using transects, were not able to accurately represent rare plant species, while dominant plant species were being overrepresented, much like archaeological surveys overrepresent high density artefact distributions and fail to detect a large proportion of low density distributions and isolated materials. Comparative studies showed that Modified-Whittalker plot outperformed traditional plant sampling designs by documenting more plant species, capturing more rare and exotic species, and more accurately representing the relative abundances of species in the surveyed community, making it also a potentially powerful tool for archaeological survey investigations. Furthermore, Modified-Whittaker strategy allows a methodological control which enables the investigation of the influence different sizes of spatial units have on patterns and processes we are able to observe, as well as how survey intensity affects data gathering and spatial patterns. Furthermore the spatial arrangement of $1 \mathrm{~m}^{2}$ frames in this strategy reduces the degree of avtocorrelation among samples, which can be substantial when transects are used (Burger et al. 2004: 411-413, 421; Burger and Todd 2006: 237-243, 251; Burger et al. 2008: 219-221; also see Stohlgren et al. 1995; 1997; 1998; Barnett and Stohlgren 2003). 


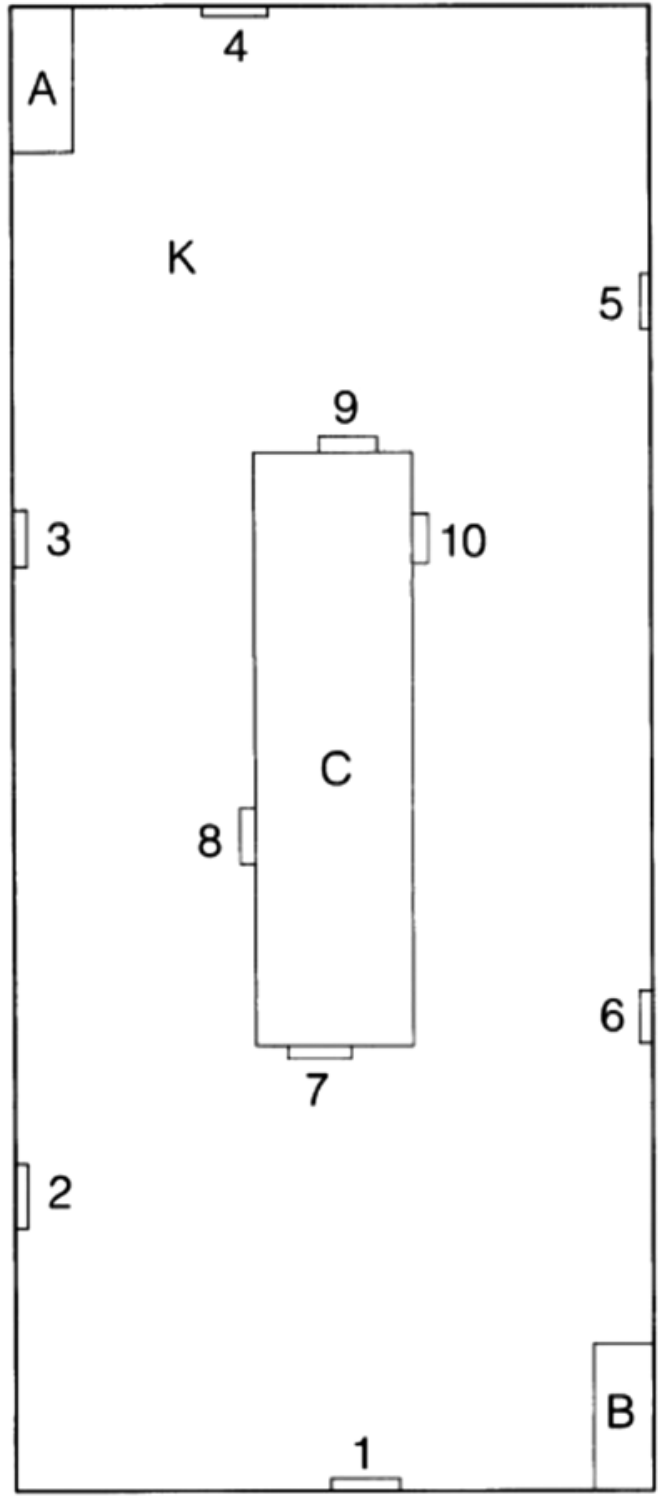

A

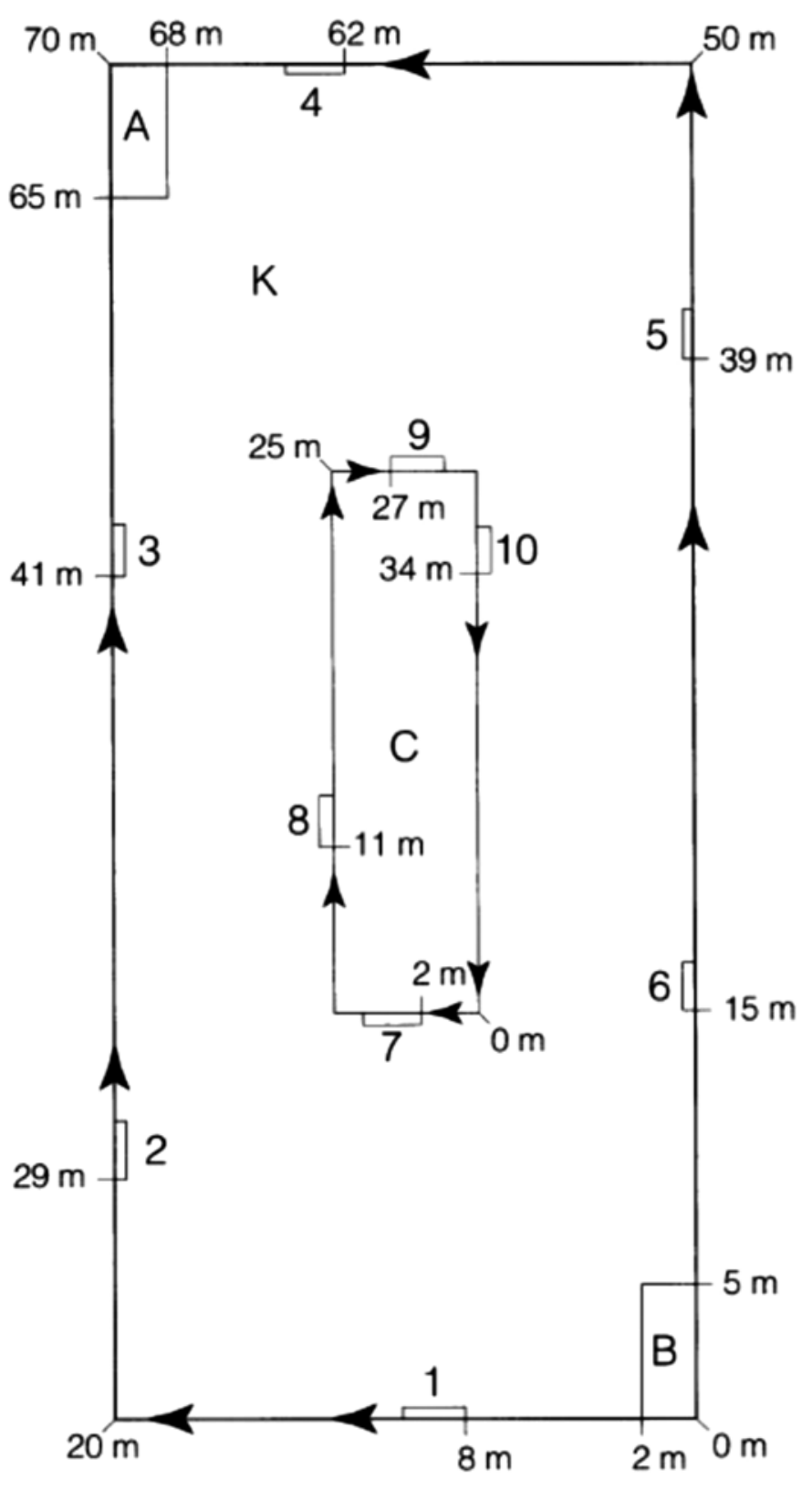

B

FIGURE 5. The Modified-Whittaker multi-scale sampling plot. (A) The layout of the $20 \times 50 \mathrm{~m}$ plot. The numbered plots (1 to 10$)$ are $0.5 \times 2 \mathrm{~m}$, the $\mathrm{A}$ and B plots are $2 \times 5 \mathrm{~m}$, and the C plot is $5 \times 20 \mathrm{~m}$. (B) Plot layout with guides for arranging subplots. The location of each subplot is indicated as a distance in meters from the anchor corner, marked by a $0 \mathrm{~m}$ in the lower right corners of the $\mathrm{K}$ plot and subplot C (Source: Burger et al. 2004: fig. 3).

sults have drastic implications about the recovery rate of such surveys and also prove the already mentioned point that without such additional property-based techniques or experiments incorporated into survey design the fraction of the sample acquired cannot be determined and interpretations of survey results based on quantitative analysis may be invalid. Furthermore, in these experiments, the results of both survey intensities were compared with test excavations of the upper 10 $\mathrm{cm}$ of the taphonomically active topsoil, results of which have worrying implications about the relationship of surface and subsurface archaeological record. The sample 
of the crawling survey was capable of predicting $72 \%$ of artefact variance in the topsoil, while the very intensive distributional survey was able to predict only $24 \%$. This means that the surface visibility of the properties of the subsurface record or in other words the capability to predict its properties on the basis of surface distributions is very poor even at great intensities let alone when using standard intensity levels of 10-15 m intervals. But nonetheless, such surveys are usually expected to detect the presence and predict the properties of much more deeply buried subsurface record, which is obviously very problematic, especially in case of development projects (Burger et al. 2004: 414-420; Burger and Todd 2006: 242243; Burger et al. 2008: 221).

As demonstrated in the case study above, the expectation that surface distributions can be used to predict the properties of subsurface archaeological record can be problematic or unrealistic. Similarly, the expectations that patterns observed in the surface record reflect past behaviour also seem unwarranted because surface distributions primarily reflect post-depositional formation
A

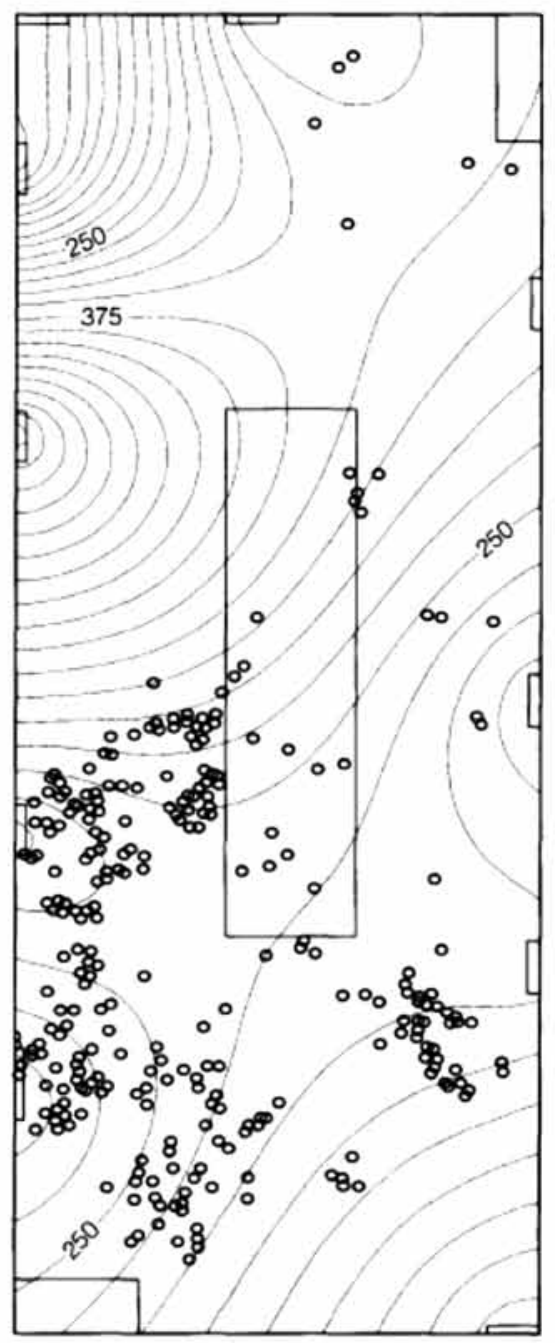

B

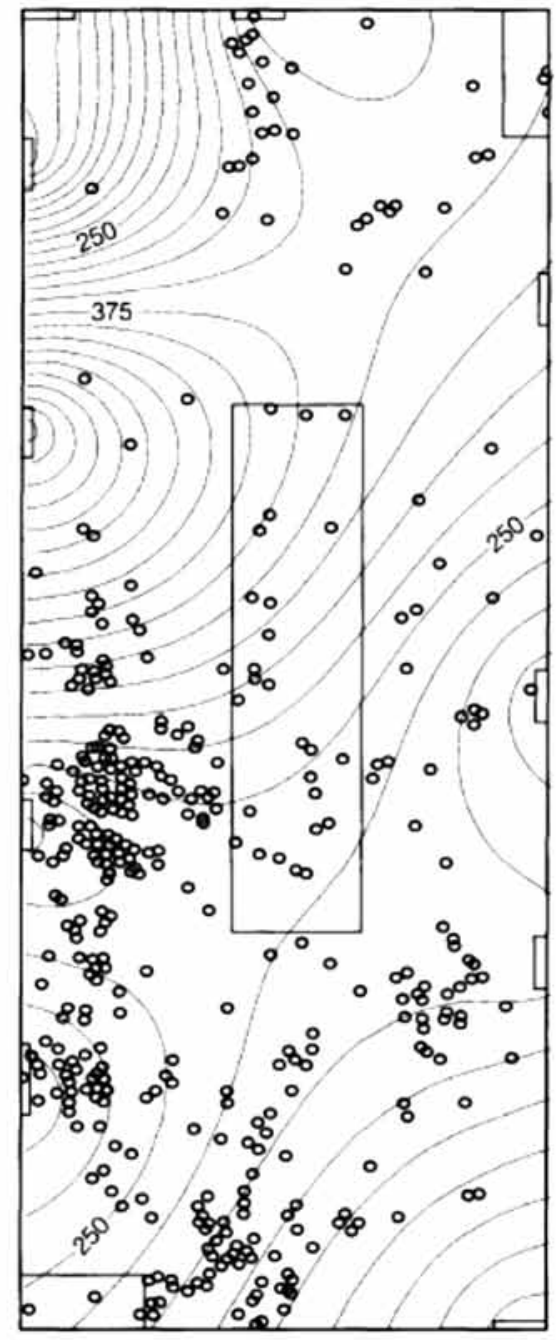

C

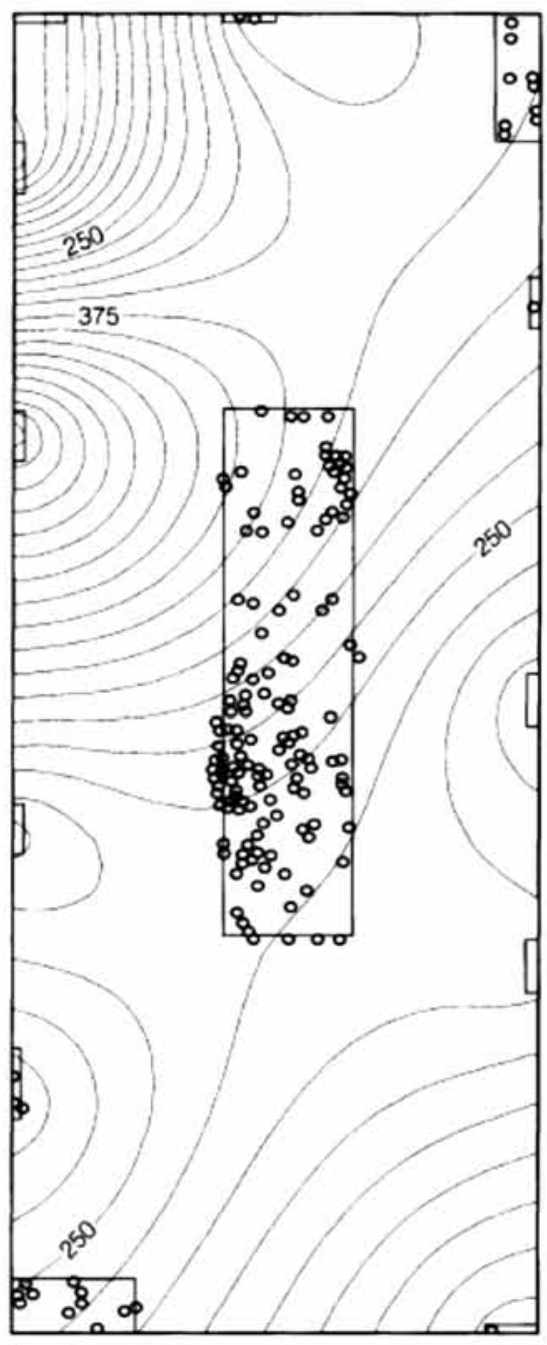

$20 \mathrm{~m}$

FIGURE 6. An example of how the surface record changes with observer intensity. Results of an experiment with Modified-Whittaker sampling strategy on plot NRT in the Oglala National Grassland. (A) Artifacts discovered by the discovery group during a systematic walking survey in $70 \mathrm{~cm}$ intervals. (B) Artifacts later discovered by the coding group, highlighting existing clusters rather than identifying new ones. (C) Crawl survey in the subplots delineated by smaller rectangles transformed the areas with relatively diffuse scatters into dense clusters. The contours are based on chipped stone recovered in the subsurface subplots 1 to 10 (see Fig. 4); the interval is 25 flakes (after Burger et al. 2004: 417, fig. 6). 


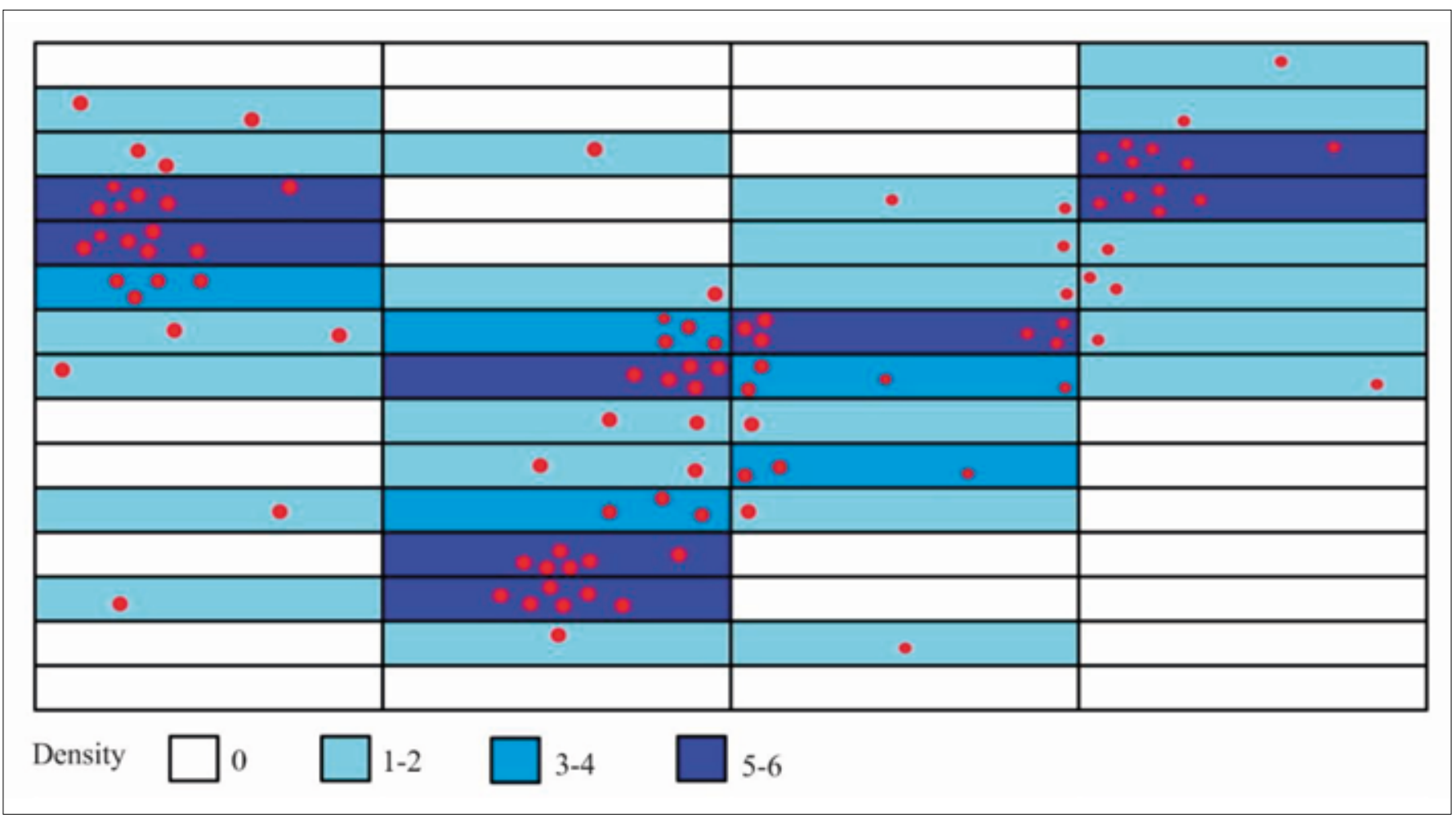

FIGURE 7. Example of a hypothetical smearing effect which occurs when using aggregate units, in this case, transects. Properties of the real distributional pattern and artefact clusters (red dots) are concealed in this aggregate unit density map.

processes or taphonomy of the landscape (see Burger et al. 2008: 203-211). But setting these interpretative problems aside an important methodological question is whether standard survey procedures even allow for documentation and recognition of realistic patterns in surface distributions? Because standard procedures use aggregate units smearing effect occurs, disguising spatial patterns and associations in the distributions we record (Fig. 7). Also by using aggregate units, which can be of different shapes and sizes, we are faced with the Modifiable Areal Unit Problem or MAUP, which is connected with the question to what degree our choice of areal units conditions the results of the analysis. This problem arises because we use arbitrary areal units for documenting a continuous space and thus obtain arbitrary spatial patterns (Harris 2006: 48). Data are ascribed to areal units, which are arbitrary and modifiable and have no natural meaning in the continuous space. However, if the units are arbitrary and modifiable than so are the results of the spatial analysis, which are heavily dependent on the shape and size of units used. Different ways of spatial data aggregation lead to an almost infinite number of possible spatial units, and patterns that result from this may vary widely and are thus an artefact of modifiable areal units and not of the archaeological phe- nomena themselves (Ibid.: 49). Modifiable areal units are the main cause of variability in spatial data interpretations because the choices of units and data aggregation process condition the patterns we may recognise. Different ways of data aggregation give different results but without any systematic trends. With the changing of areal units we arrive to different statistical results and generally the bigger the unit the greater the correlation between two variables. Thus, bigger areal units cause greater stability in the results and mask important spatial variations, which could be discerned if smaller units were used (Fig. 8) (Ibid.: 46, 49-50).

Incapability of discerning between spatial associations of data aggregated into units and real associations of unmodifiable individual data is endemic to all kinds if analyses based on spatial data aggregated into units. Thus, techniques of data collection which are not dependent on the frame and which allow joining and disjoining of data in different ways are called for (Harris 2006: 50-51). In the case of the surface survey, the only solution to this problem seems to be the use of point provenience instead of data aggregation. With the rapid development of GPS technology, it is now possible to do this in an efficient way and many survey archaeologists have 
recently called for the need of point provenience or artefact accurate survey (see Wessel and Wohlfarth 2008: 15-18, 42-43; García-Sánches 2013; García-Sánches and Cineros 2013: 297-299; García-Sánches and Ezquerro 2014; Trachet et al. 2017; de Neef et al. 2017: 285, 296; Gruškovnjak 2017b), which allows for recognition of real distributional patterns and spatial associations. However, such high resolution surveys may bring forth the problem of surface coverage because more work hours are needed to accomplish it, and despite the high data resolution and their representativeness within a small area, such an area may be too small to be representative and useful from the regional point of view (e.g. Bintliff 2000: 205; Fentress 2000: 44, 50-51). By lowering the intensity of the survey, the speed of discovering new data is increased, but their resolution is decreased (Burger and Todd 2006: 247-248, fig. 15-5). This is caused by the interaction of two main aspects of visibility, determined by survey strategy or two reasons why different survey strategies do not discover cultural material: (1) sacrifice of space or coverage - smaller the coverage less material will be discovered; (2) sacrifice of intensity - lower the intensity, less material will be discovered. This is an insurmountable problem because both sacrifices are inevitable and unacceptable at the same time. Regarding this, the difficult question is: "What is a better way not to discover artefacts, by not looking in enough places or by not looking closely enough?" The need for archaeological resource management and protection on the regional level, the fact that archaeologists will never know where all cultural material in the landscape is located as well as restrictions of time and resources probably call for continued use of conventional survey procedures. However, at least one phase of survey design should include control experimental surveys at different scales and intensities, which would then allow a quantitative understanding of these methodological sacrifices and a better understanding of the regional surface record (Burger et al. 2004: 420). As an ideal frame for such property-based investigations, the already mentioned Modified-Whittaker sampling strategy (Fig. 5) has been proposed, while other options are also worth exploring ${ }^{13}$.

13 Another strategy for property-based investigation that could also be borrowed from landscape ecology surveys, is the North Carolina Vegetation Survey (NCVS) nested plot (Peet et al. 1998). At least one comparative study (Goslee 2006) shows that it performs just as well as the Modified-Whittaker plot, but in comparison, it might be easier to set up and modify according to field circumstances. Jet another option for property-based investigations could be the use of pointsampling (Van de Velde 2001), combined with a standard survey procedure using transects or quadrats. With point sampling areas of around 2 square meters spaced in regular intervals are thoroughly cleaned and inspected which insures the discovery and collection of all artefacts present on the surface and enables comparisons with the results of standard procedure. This possibility for using point-sampling

\section{$4^{\text {th }}$ level determining visibility: surface and other envi- ronmental conditions during the survey}

The fourth level that determines visibility is connected with surface conditions, accessibility and other environmental conditions during the time of the survey. Some surfaces are not accessible due to strong vegetation, difficult terrain, buildings or due to owners who prevent access and such areas cannot be surveyed. Because of such factors, total coverage of survey area is almost never possible and consequently, we are always dealing with surface samples or incomplete distributions (Schiffer et al. 1978: 8-10; Terrenato 1996: 223-224). The effectiveness of the survey is affected by different environmental conditions such as lighting conditions, weather conditions, flora and fauna etc. (e.g. Chapman 1989: 57; Barker 1996: 167). Among generally measured aspects of surface visibility is the assessment of surface exposure in relation to groundcover, usually measured with 1 to 10,10 being $100 \%$ of the surface is exposed (see Bintliff 1985: 210; Gallant 1986: 406; Cherry et al. 1991: 27-28; Gaffney et al. 1991: 61; Terrenato 1996: 223; Terrenato 2000: 60, 66). However, a variety of other factors also

has been proposed by Jitte Wagner at the Finds in the Landscape. New Perspectives and Results from Archaeological Surveys. / Funde in der Landschaft. Neue Perspektiven und Ergebnisse archäologischer Prospektion international conference, held on June 12th-13th at the Fritz Thyssen Stiftung in Cologne, Germany. There he presented point sampling as a subsampling technique performed in $10 \mathrm{~m}$ intervals as it was used in the case of Tappino Valley Survey (2013-2017), results of which have not jet been published (see Gruškovnjak 2017b; also see the comment on point sampling technique by Burger et al. 2004: 420-421)

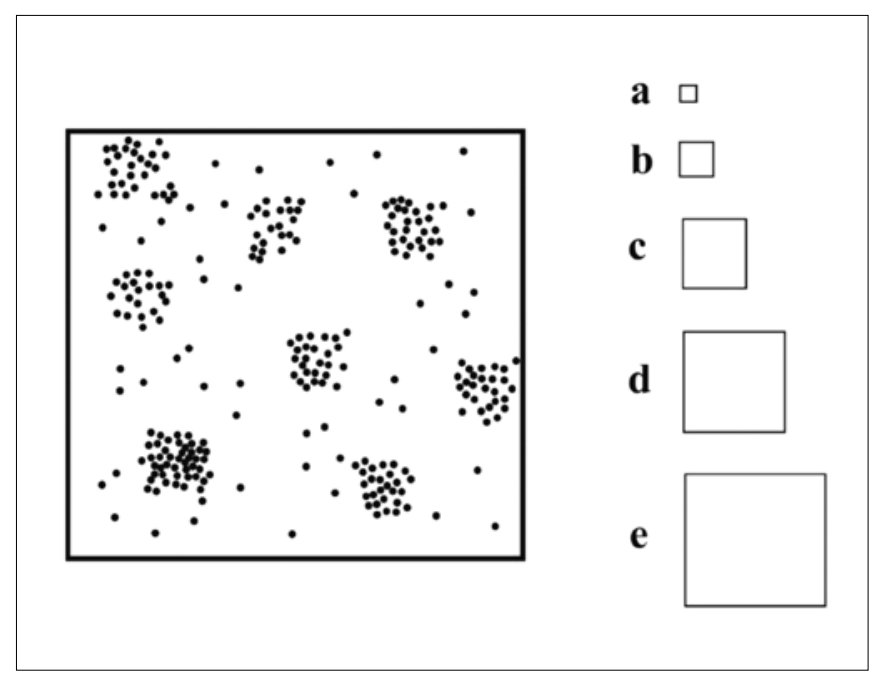

FIGURE 8. Example of a hypothetical distribution pattern showing the differences that can result from using different sample unit sizes. Sampling with smaller quadrats ( $a$ and $b$ ) would suggest slight clustering, with intermediate quadrats (c) strong clustering, and with large quadrats ( $d$ and e) regularity (Source: Plog 1976: fig. 5.3). 
A
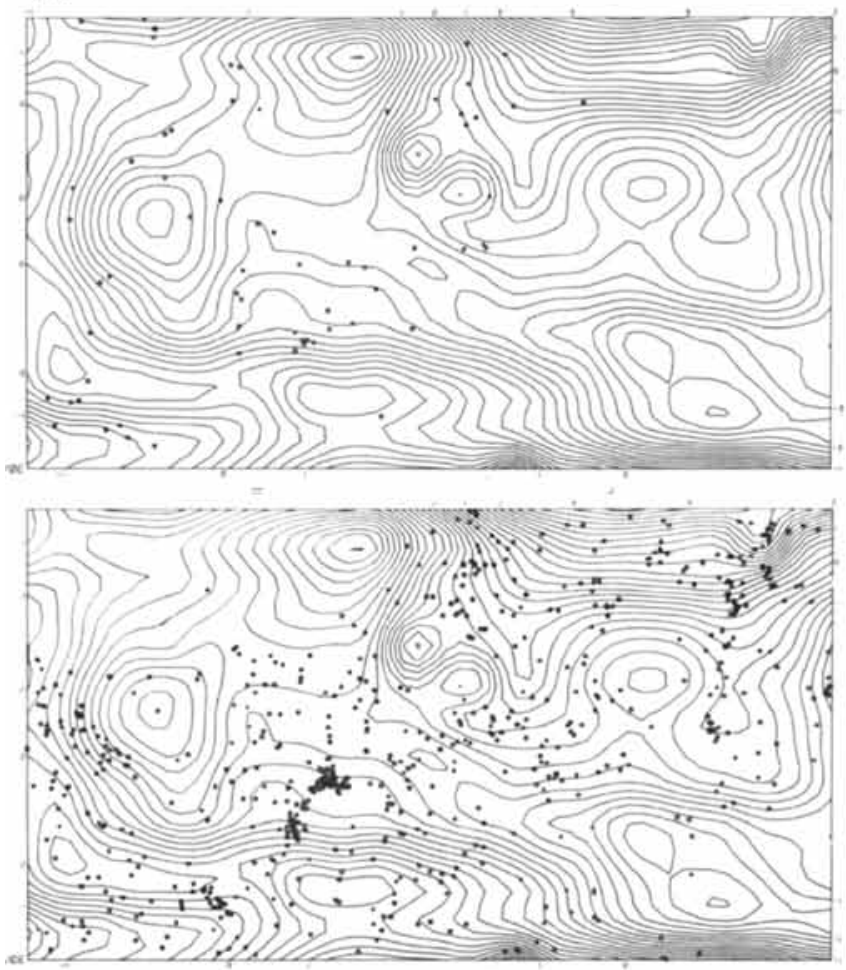

$\mathrm{C}$

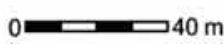
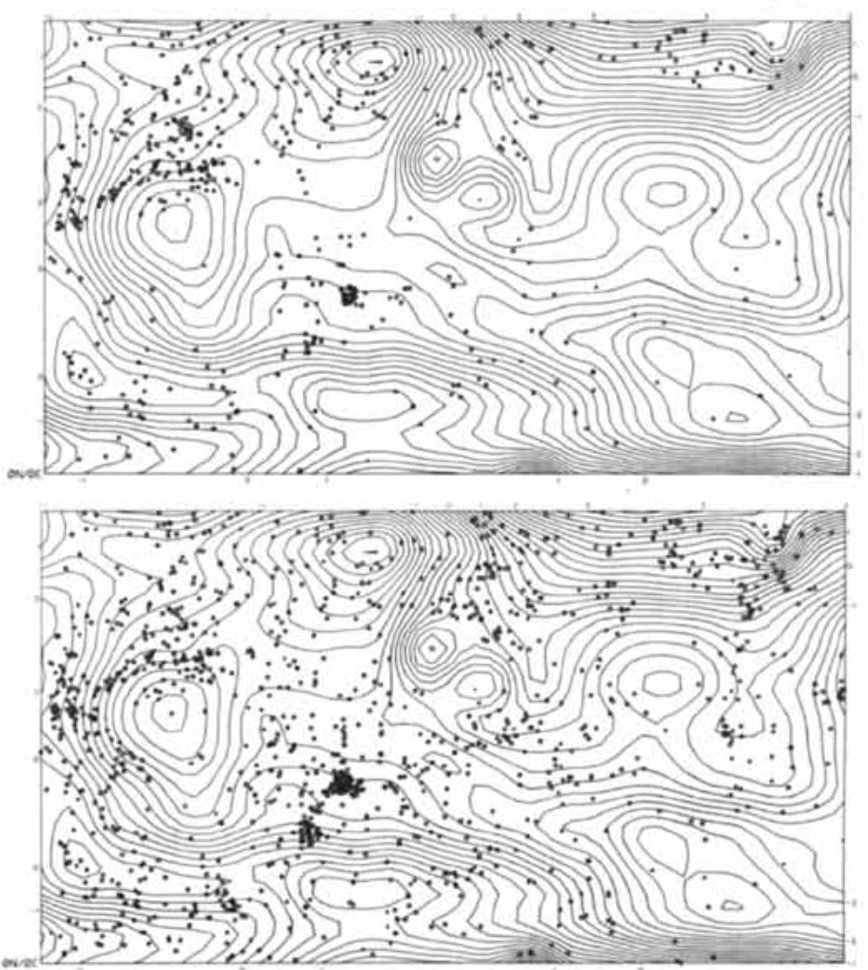

contour interval $20 \mathrm{~cm}$

FIGURE 9. Comparison of consecutive collection phases (a) on an unmodified surface, (b) on a ploughed surface, (c) on a disked surface and (d) a representation of joined results of all three phases of the surface collection. Each of collection phases was done after rain (Source: Jermann 1981: Fig. 3.5-8).

affect visibility which is why simple correction formulae (see Bankoff and Winter 1982: 152; Bintliff 1985: 210; Bintliff 2000: 204; Bankoff et al. 1989: 65, tab. 1; Gaffney et al. 1991: 64; Terrenato 2000: 66-69) cannot rectify all the biases that differential visibility conditions incorporate into survey results (see e.g. Banning et al. 2006: 739-740). These other factors for example include phase in the cultivation cycle and plant rotation, type of soil, colour and composition of the soil matrix, type of vegetation, relief, type of surface treatment (ploughing, disking), rain before survey etc. (see Hirth 1978: 126, 130; Jermann 1981: 79-82, 88; Gallant 1986: 406; Bankoff et al. 1989: 65, 69, tab. 1; Barton et al. 2002: 164; Banning et al. 2017: 473). The main problem in the assessment of visibility, however, is that it is very hard or impossible to formalize and realistically quantify the effects of the interaction of all such factors on surface visibility. Furthermore, gathering data on these factors is usually done by using aggregate units, and consequently subjected to the Modifiable Aerial Unit Problem (see above).
An example of the effects of surface treatment (ploughing and disking) as well as differences in soil types and micro-relief, is provided by a survey performed on a site 45-SA-17b in SW Washington, U.S.A., presented by V. Jermann (1981). There one is able to see a comparison between three consecutive phases of surface survey, first on an unmodified surface, then on a ploughed surface and last on a disked surface (Fig. 9). The differences in recovery rate between these phases were drastic: unmodified surface yielded 80 artefacts, ploughed surface yielded 600 artefacts, and disked surface yielded 750 artefacts. In addition, each consecutive phase recovered more artefacts of smaller sizes and lower weights than the previous phase. Because of the effects that ploughing and disking have on surface visibility, it has been suggested on several occasions that every surface should be prepared by ploughing and disking before the survey, though this is only acceptable in case of already cultivated or otherwise disturbed surfaces. Besides the differences in the number, size and weight of artefacts, there 
were also differences in spatial distributions between the three collection phases on the undulating surface of the surveyed field. Artefacts recovered in the first phase were generally confined to the central and lower slopes of major hillocks, which also correspond to parts of the survey area exhibiting sandier soils. This spatial pattern is probably connected with the effects of long-term exposure and eolian action on these dune-like hillocks, while in the parts exhibiting more silty or clayey soils the precipitation caused "puddling" which subsequently obscured the surface, and colluvial sediments accumulating between hillocks buried any artefactual remains. The difference between sandy and silty soils was particularly evident in the post-ploughing and post-disking collections. The northeast portion of the area is characterised by much sandier soils, and post-ploughing recovery rates were considerably higher in these sandier soils. Silty soils require much more intensive mechanical preparation to render optimal exposures as evident in the post-disking collection, which yielded a much higher number of artefacts on siltier surfaces than previous phases (Ibid.: 7379, 83-88).

\section{$5^{\text {th }}$ level determining visibility: the human factor}

The fifth level determining visibility is the human factor or fieldworkers themselves for in the end it depends on them what will actually be noticed and collected in the field. Survey is done with "sentient instruments" capable of learning, boredom, exhaustion and so on, so the accuracy of measurements or effectiveness of recovery may vary according to their experiences, skills, motivation, interest, talent, visual focus, mood, health, fitness etc. (e.g. Schiffer et al. 1978: 14; Wandsnider and Camilli 1992: 185; Barker 1996: 167; Banning 2002: 65; Hawkins et al. 2003: 1504; Banning et al. 2017: 472, 484).

One of the greatest problems concerning human factor here is that in the presence of a mixture of different types and/or colours of artefacts our attention and visual perception becomes unequally distributed and biased towards and/or against some of the types and/or colours of artefacts (Banning et al. 2011: 3454). The most problematic, even in the case of experienced workers, is the visual focus on ceramic artefacts, while recovery of stone artefacts is extremely low. To ensure the discovery of stone artefacts besides the ordinary field team a specialist for stone artefacts would be needed to inspect the surface only for this type of finds. In Boeotia Survey, for example, experimentations with a lithic specialist collecting only stone artefacts resulted in 1 tool per hectare discovered by the specialists, while the average for the rest of the fieldwalking team was zero (Bintliff 2000: 207).

Other ways to control and evaluate inter-observer bias have also been proposed. Control seeding experiments and resurveys, especially with property-based investigations, mentioned above in the context of second and third levels determining visibility, are already two procedures which can prove invaluable in evaluating interobserver biases (see Banning 2002: 214; Hawkins et al. 2003: 1504; Banning et al. 2017: 474-476). Also, some basic steps which allow for the evaluation of inter-observer bias must be followed in any survey design. An essential first step is to track the work of different collectors by recording specific units they survey. If fieldworkers follow a consistent pattern of examining alternating transects, the evaluation of inter-observer biases is more effective, because the principle of autocorrelation can be used to advantage during the analysis. Evaluation is also made easier when transects are spaced at close intervals. It is also important for crews to mix fieldworkers of different experience and skill levels. In addition, crews and fieldworkers should be allocated in such a way to enable easy distinguishing of their respective abilities from spatial variation. For example, allocating each crew and/ or fieldworker to equal numbers of survey units in each stratum of the survey area stratified according to different visibility conditions (according to $1^{\text {st }}, 4^{\text {th }}$ and possibly $2^{\text {nd }}$ level) simplifies evaluation. Monitoring and documenting health, mood etc. of crew members can also prove valuable when comparing results of different survey areas. Training the crew members is obviously also essential. All fieldworkers should be familiar with the kinds of materials, site characteristics, subsurface feature characteristics, visibility conditions etc. that might be expected in the survey area, as well as trained to scan the surface in the same and consistent way. Motivating crew members is also an important factor as most highly motivated people will report most material. Motivation could possibly be stimulated by increasing continuity between fieldwork and analysis as well as involving staff in the publication of results (Banning 2002: 66; Hawkins et al. 2003: 1506, 1507-1508, 1510-1511).

Determining detection functions of each surveyor has also been proposed by Hawkins et al. (2003) and Banning et al. $(2006$; 2011; 2017) as a way to allow for the analysis of inter-observer biases in survey results. This is done by testing surveyors' abilities to detect different types of artefacts under different controlled but realistic field conditions, in both cases such as are anticipated in the specific survey area (Fig. 10). For this purposes, 20 $\mathrm{m}$ wide and $100 \mathrm{~m}$ long experimental plots are set up on 
calibration fields characterized by environmental conditions present in the survey area. The plots are overlain with a $2 \mathrm{~m}$ grid and longitudinally divided into two halves with a clearly visible rope. A known number of artefacts, simulating characteristics of archaeological materials anticipated in the survey area, is seeded throughout the plot in such a way that each long column in the grid would have the same number of artefacts of each type in a randomized position along the column. Crew members are then asked to walk along the central line without leaving it and record the positions of the finds they spot on a sheet with a corresponding grid. Such an experimental design might seem similar to the already mentioned control seeding experiments incorporated into survey design, however, in this instance, the experiment is performed differently and not as part of the field collection and also serves somewhat different purposes. It enables the determination of detection functions for each crew member in relation to different characteristics of artefacts and environmental conditions. Simply put, it shows to what distance laterally from the transect line crew members are able to spot a satisfying fraction of different types of artefacts in different field conditions. Such data can be invaluable when deciding on survey design, specifically optimal transect intervals which will ensure the same level of detectability in different visibility conditions of the stratified survey area. Furthermore, through the use of exhaustion maps ${ }^{14}$ in the analysis of survey results this data will allow for a realistic evaluation of inter-observer biases in the recorded artefact types and densities, which might otherwise be severely limited or impossible. Thus, with the use of such experiments one is able to adjust the survey strategy (intensity or sweep width) and evaluate inter-observer biases according to capabilities of any specific field crew in any specific survey area. Preferably such experiments would be performed repeatedly over the course of a survey project in order to control for maturation and history and produce "average" results (Hawkins et al. 2003: 1509; Banning et al. 2006: 728-730, 737-741; Banning et al. 2011; Banning et al. 2017: 478-481).

14 Exhaustion maps of surveyed areas allow us to determine whether density variations in the distribution maps might be due to thoroughness of survey rather than real variations in the evidence present in the field. On such a map, each survey unit or collection unit shows the average detection rate of the crew members who worked there as an estimate of unit's exhaustion or thoroughness of survey. Units with high detection rate have a lower probability of overlooked evidence, while units with low detection rate have a higher probability of overlooked evidence and might be far from exhausted. Plotting artefact or site distributions on exhaustion maps shows how much the distributions may depend on the degree of exhaustion. It can also provide direction for decision making about which areas need to be rechecked in the subsequent phases of the survey or in future survey projects (Hawkins et al. 2003: 1509, fig. 6; Banning et al. 2017: 482483, fig. 6; also see Banning 2002: 220-223).

\section{Conclusions}

All the levels determining the visibility of archaeological record on the surface are in complex interactions and it is very hard to formalize their effects and realistically account for them let alone correct all the biases they incorporate into survey results. Nonetheless, we should strive towards accounting for them as precisely as possible by incorporating additional methodological procedures into survey designs. These should include initial geomorphological and pedological mapping followed by stratification of the survey area according to properties of the $1^{\text {st }}, 4^{\text {th }}$ and possibly $2^{\text {nd }}$ level determining visibility and modifying the survey design according to these properties and experimentally determined crew member detection functions. Very precise descriptions of the soil matrix, micro-topography and other environmental variables need to be documented during fieldwork. Also, phases with control seeding experiments and/or property-based investigations incorporated into survey design may be the only way to allow for a realistic evaluation of precision, reliability and accuracy of survey results. And as the surface survey is an inherently biased discovery method multiple survey methods detecting different types of constituents of archaeological record are called for.

We should also realize what it is we are primarily discovering with the surface survey. The surface survey is not a discovery method, which would show the presence or absence of archaeological resources in the survey area. Instead, this method is geared towards discovering only disturbed and exposed archaeological record. From this point of view, this method primarily allows us to study post-depositional disturbance processes in the landscape or landscape taphonomy (see Burger et al. 2008) and its effects on the archaeological record. Thus, the surface survey can never be expected to reveal a complete distribution of archaeological remains still preserved in the landscape, let alone a complete distribution that once existed in that landscape.

In addition, we should be aware of the difference between the totality of archaeological record and the archaeological record as it is realised through our investigation methods during which loss of information or imperfect realisation of the archaeological record is inevitable. This is because the accuracy, reliability and precision of our methods are conditioned by a multitude of factors, archaeological record itself being only one of them. 
FIGURE 10. An example of assessing crew detection functions on calibration fields in Jordan and Cyprus. In the upper part are views of the plots:

a) pasture,

b) olive grove,

c) guava orchard,

d) mixed field, all in Jordan,

e) stubble field, and f) ploughed a field in Cyprus.

Below are detection functions for all lithics (solid curve) and all pottery (dashed curve) along with half the corresponding sweep widths (vertical lines) at the corresponding calibration sites. $p(r)$ is detection probability at range $r$ and $r$ is a range in meters

(Source: Banning et al. 2017: fig. 3-4).
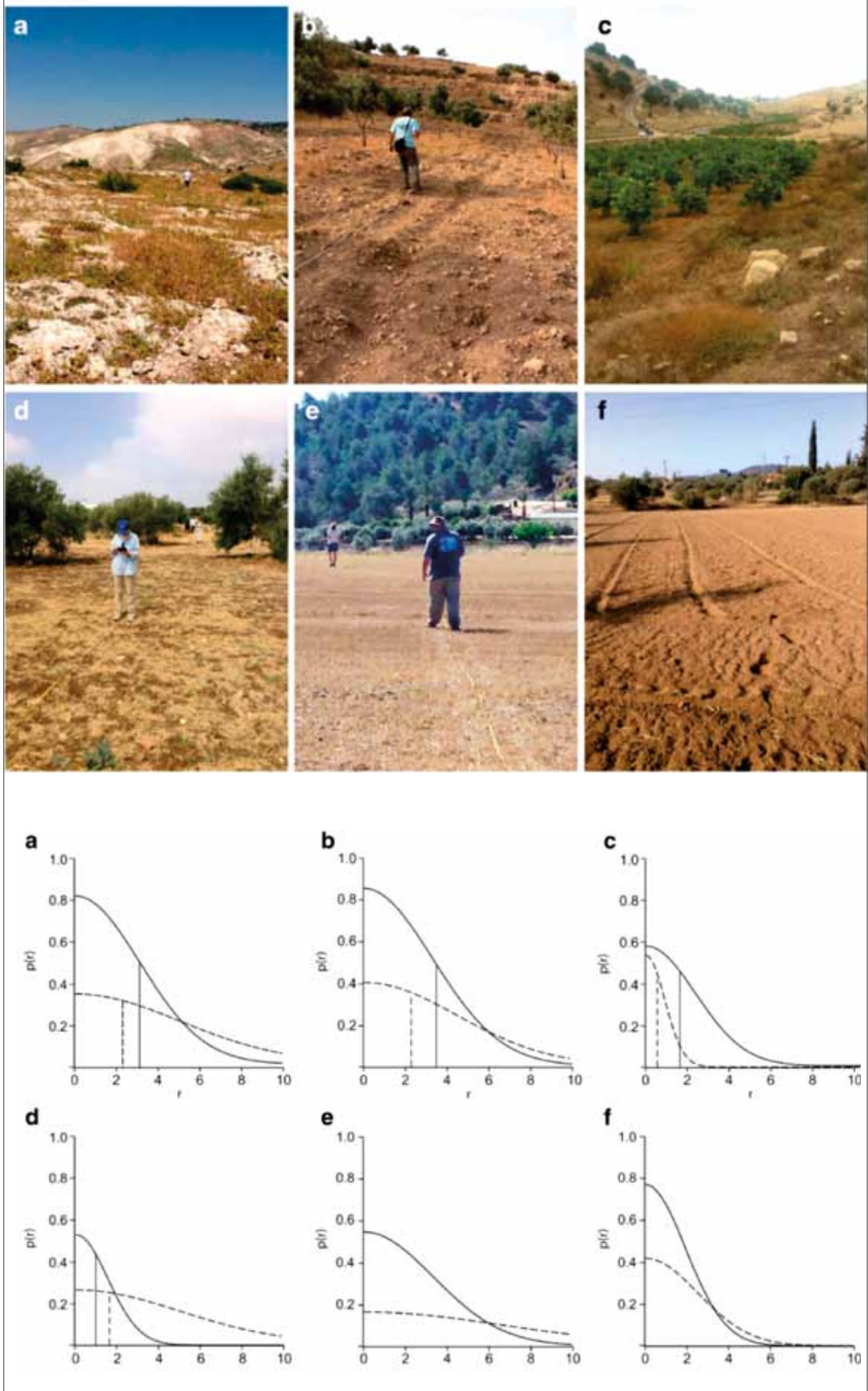


\section{References}

Ammerman, A. J. 1981. Surveys and Archaeological Research, Annual Review of Anthropology 10, 63-88.

Ammerman, A. J. 1985. Plow-Zone Experiments in Calabria, Italy, Journal of Field Archaeology 12 (1), 33-40.

Araujo, A. G. M. 2013. Bioturbation and the upward movement of sediment particles and archaeological materials: comment on Bueno et al., Journal of Archaeological Science 40, 2124-2127.

Atkinson, R. J. C. 1957. Worms and Weathering, Antiquity 31, 219-233.

Balek, C. L. 2002. Buried Artifacts in Stable Upland Sites and the Role of Bioturbation: A Review, Geoarchaeology: An International Journal 17 (1 - Special Issue: Site Formation Processes in Regional Perspective: Part I), 41-51.

Bankoff, H. A. and Winter, F. A. 1982. The Morava Valley Project in Yugoslavia: Preliminary Report, 1977-1980, Journal of Field Archaeology 9 (2), 149-164.

Bankoff, H. A., Bomberault, A., Greenfield, H. and Winter, F. A. 1989. Strategija arheološkega vzorčenja najdišča v coni zmernega okolja, Arheo 9, 64-73.

Banning, E. B. 2002. Archaeological Survey, Manuals in Archaeological Method, Theory, and Technique, Springer Science+Business Media, New York.

Banning, E. B., Hawkins, A. and Stewart, S. T. 2006. Detection Functions for Archaeological Survey, American Antiquity 71 (4), 723-742.

Banning, E. B., Hawkins, A. and Stewart, S. T. 2010. Detection Functions in the Design and Evaluation of Pedestrian Surveys, In: F. Niccolucci and S. Hermon (eds.), Beyond the Artefact. Digital Interpretation of the Past. Proceedings of CAA2004, Prato 13-17 April 2004, Archaeolingua, Budapest, 123 -124.

Banning, E. B., Hawkins, A. and Stewart, S. T. 2011. Sweep widths and the detection of artifacts in archaeological survey, Journal of Archaeological Science 38 (12), 3447-3458.

Banning, E. B., Hawkins, A., Stewart, S. T., Hitchings, P. and Edwards, S. 2017. Quality Assurance in Archaeological Survey, Journal of Archaeological Method and Theory 24 (2), 466-488.

Barker, G. 1996. Regional archaeological projects, Archaeological Dialogues 3 (2), 160-175.

Barnett, D. T. and Stohlgren, T. J. 2003. A nested-intensity design for surveying plant diversity, Biodiversity and Conservation 12 (2), 255-278.

Barton, C. M., Bernabeu, J., Aura, J., E., Garcia, O. and La Roca, N. 2002. Dynamic Landscapes, Artifact Taphonomy, and Landuse Modeling in the Western Mediterranean, Geoarchaeology: An International Journal 17 (2- Special Issue: Site Formation Processes in Regional Perspective: Part II), 155-190.
Bettis, E. A. and Mandel, R. D. 2002. The Effects of Temporal and Spatial Patterns of Holocene Erosion and Alluviation on the Archaeological Record of the Central and Eastern Great Plains, U.S.A., Geoarchaeology: An International Journal 17 (2- Special Issue: Site Formation Processes in Regional Perspective: Part II), 141-154.

Bintliff, J. 1985. The Boeotia Survey, In: S. Macready and F. H. Thompson (eds.), Archaeological Field Survey in Britain and Abroad, Occasional Papers 6, Society of Antiquaries of London, London, 196-216.

Bintliff, J. 1996. Interactions of theory, methodology and practice: Retrospect and commentary, Archaeological Dialogues 3 (2), 246-25.

Bintliff, J. 2000. The concepts of "site" and "offsite" archaeology in surface artefact survey, In: M. Pasquinucci and F. Trément (eds.), Non-destructive techniques applied to Landscape Archaeology. The Archaeology of Mediterranean Landscapes 4, British School at Athens, Oxford, 200-215.

Bintliff, J. and Snodgrass, A. 1985. The Cambridge/Bradford Boeotian Expedition: The First Four Years, Journal of Field Archaeology 12 (2), 123-161.

Bintliff, J. and Snodgrass, A. 1988. Off-Site Pottery Distributions: A Regional and Interregional Perspective, Current Anthropology 29 (3), 506-513.

Bocek, B. 1986. Rodent Ecology and Burrowing Behaviour: Predicted Effects on Archaeological Site Formation, American Antiquity 51 (3), 589-603.

Boismier, W. A. 1989. Recognizing and controlling for cultivation-induced patterning in surface artefact distributions, In: S. Rahtz and J. Richards (eds.), Computer Applications and Quantitative Methods in Archaeology 1989. CAA1989, BAR Internationa Series 548, British Archaeological Reports, Oxford, 132-146.

Brookes, I. A., Levine, L. D. and Dennell, R. W. 1982. Alluvial Sequence in Central West Iran and Implications for Archaeological Survey, Journal of Field Archaeology 9 (3), 285-299.

Burger, O. and Todd, L. C. 2006. Grain, Extent, and Intensity: The Components of Scale in Archaeological Survey, In: G. Lock and B. L. Molyneaux (eds.), Confronting Scale in Archaeology. Issues of Theory and Practice, Springer Science+Business Media, LLC, New York, 235-255.

Burger, O., Todd, L. C., Burnett, P., Stohlgren, T. J. and Stephens, D. 2004. Multi-Scale and Nested-Intensity Sampling Techniques for Archaeological Survey, Journal of Field Archaeology 29 (3-4), 409-423.

Burger, O., Todd, L. C. and Burnett, P. 2008. The Behavior of Surface Artifacts: Building a Landscape Taphonomy on the High Plains, In: L. L. Scheiber and B. J. Clark (eds.), Archaeological Landscapes on The High Plains, University Press of Colorado, Boulder, 203-236. 
Butzer, K. W. 1982. Archaeology as human ecology, Cambridge University Press, Cambridge etc.

Chapman, J. 1989. Metodologija terenskega pregleda projekta Neotermalna Dalmacija, Arheo 9, 55-57.

Cherry, J. F., Davis, J. L., Matzourani, E. and Whitelaw, T. M. 1991. The Survey Methods, In: J. F. Cherry and E. Mantzourani (eds.), Landscape Archaeology as Long-Term History. Northern Keos in the Cycladic Islands from Earliest Settlement until Modern Times, Institute of Archaeology, University of California, Los Angeles, 13-35.

de Neef, W. K, Armstrong, K. and van Leusen, M. 2017. Putting the Spotlight on Small Metal Age Pottery Scatters in Northern Calabria (Italy), Journal of Field Archaeology 42 (4), 283-297.

Dunell, R. C. and Simek, J. F. 1995. Artifact Size and Plowzone Processes, Journal of Field Archaeology 22 (3), 305319.

Ebert, J. I., Larralde, S. and Wandsnider, L. 1987. Distribution Archaeology: Survey, Mapping, and Analysis of Surface Archaeological Materials in the Green River Basin, Wyoming, In: A. J. Osborn and R. C. Hassler (eds.), Perspectives on Archaeological Resources Management in the Great Plains, I \& O Pub. Co., Omaha, 159-177.

Erlandson, J. M. 1984. A Case Study in Faunalturbation. Delineating the Effects of the Burrowing Pocket Gopher on the Distribution of Archaeological Materials, American Antiquity 49 (4), 785-790.

Fentress, E. 2000. What are we counting for?, In: R. Francovich and $\mathrm{H}$. Patterson (eds.) Extracting meaning from Ploughsoil Assemblages. Archaeology of Mediterranean Landscapes 5, Oxbow Books, Oxford, 44-52.

Foley, R. 1981. Off-site archaeology: an alternative approach for the short-sited, In: I. Hodder, G. Isaac and N. Hammond (eds.), Patterns of the past. Studies in honour of David Clarke, Cambridge University Press, Cambridge etc., 157-183.

Gaffney, V. L., Bintliff, J. and Slapšak, B. 1991. Site Formation Processes and the Hvar Survey Project, Yugoslavia, In: A. J. Schofield (ed.), Interpreting Artefact Scatters, Contributions to Ploughzone Archaeology, Oxbow Monograph 4, Oxbow Press, Oxford, 59-77.

Gallant, T. W. 1986. "Background Noise" and Site Definition: A Contribution to Survey Methodology, Journal of Field Archaeology 13 (4), 403-418.

García-Sánches, J. 2013. Metodologías de prospección a escala regional y artefactual en la comarca. La prospección del Ager Segisamonensis; comarca Odra-Pisuerga (Burgos). / Field survey methodology in regional and artefactual scale. The Ager Segisamonensis Survey Project, Odra-Pis, Complutum, 24 (1), 9-28.

García-Sánches, J. and Cisneros, M. 2013. An Off-Site Approach to Late Iron Age and Roman Landscapes on the Northern Plateau, Spain, European Journal of Archaeology, 16 (2), 289-313.
García-Sánches, J. and Ezquerro Cordón, A. 2014. New techniques for artefactual surveying: GIS-GPS methodology for the study of Roman habitational context, In: A. García Moreno, J. García Sánchez, A. Maximiano Castillejo and J. Rios Garaizar (eds.), Debating Spatial Archaeology. Proceedings of the International Workshop on Landscape and Spatial Analysis in Archaeology. Santander, June 8th -9th, 2012, Instituto Internacional de Investigaciones Prehistóricas de Cantabria, 225-230.

Goslee, S. C. 2006. Behaviour of vegetation sampling methods in the presence of spatial autocorrelation, Plant Ecology 187(2), 203-212.

Gruškovnjak, L. 2017a. Arheološki površinski pregled - osnovni koncepti in problemi, Arheo 34, 23-77.

Gruškovnjak, L. 2017b. Arheološki površinski pregled v luči najnovejše diskusije - Poročilo s konference Finds in the Landscape. New Perspectives and Results from Archaeological Surveys. / Funde in der Landschaft. Neue Perspektiven und Ergebnisse archäologischer Prospektion, 12. 13. junij 2017, Köln, Nemčija, Arheo 34, 105-121.

Harris, T. M. 2006. Scale as Artifact: GIS, Ecological Fallacy, and Archaeological Analysis, In: G. Lock and B. Molyneaux (eds.), Confronting Scale in Archaeology. Issues of Theory and Practice, Springer Science+Business Media, LLC, New York, 39-53.

Hawkins, A., Stewart, S. and Banning, E. 2003. Interobserver bias in enumerated data from archaeological survey, Journal of Archaeological Science 30 (11), 1503-1512.

Hey, G. 2006. Scale and Archaeological Evaluations: What are We Looking For?, In: G. Lock and B. L. Molyneaux (eds.), Confronting Scale in Archaeology. Issues of Theory and Practice, Springer Science+Business Media, LLC, New York, 113-127.

Hey, G. and Lacey, M. 2001. Evaluation of archaeological decision-making processes and sampling strategies: European Regional Development Fund Interreg IIC - Planarch Project, Oxford Archaeological Unit, Kent County Council, Oxford.

Hirth, K. G. 1978. Problems in Data Recovery and Measurement in Settlement Archaeology, Journal of Field Archaeology 5 (2), 125-131.

Hope-Simpson, R. 1984. The Analysis of Data from Surface Surveys, Journal of Field Archaeology 11 (1), 115-117.

Jermann, V. 1981. Surface collection and analysis of spatial pattern: an archaeological example from the Lower Columbia River valley. In: M. J. O'Brien and D. E. Lewarch (eds.), Plowzone Archaeology: Contributions to Theory and Technique, Vanderbilt University, Nashville, 71-118.

Johnson, D. L. 1989. Subsurface Stone Lines, Stone Zones, Artifact-Manuport Layers, and Biomantles Produced by Bioturbation via Pocket Gophers (Thomomys Bottae), American Antiquity 54 (2), 370-389.

Johnson, D. L. 1993. Dynamic Denudation Evolution of Tropical, Subtropical and Temperate Landscapes with 
Three Tiered Soils: Toward a General Theory of Landscape Evolution, Quaternary International 17, 67-78.

Johnson, D. L. 2002. Darwin Would Be Proud: Bioturbation, Dynamic Denudation, and the Power of Theory in Science, Geoarchaeology: An International Journal 17 (1Special Issue: Site Formation Processes in Regional Perspective: Part I), 7-40.

Lewarch, D. E. 1979. Effects of tillage on archaeological pattern: a preliminary assessment. In: M. J. O'Brien and R. E. Warren (eds.), Cannon Reservoir Human Ecology Project - a regional approach to cultural continuity and change. The University of Nebraska, Department of Archaeology, Technical Report No. 79-14, 101-149.

Lewarch, D. E. and O'Brien, M. J. 1981a. The Expanding Role of Surface Assemblages in Archaeological Research, In: M. B. Schiffer (ed.), Advances in Archaeological Method and Theory, Vol. 4, Academic Press, New York etc., 297342.

Lewarch, D. E. and O'Brien, M. J. 1981b. Effect of Short Term Tillage on Aggregate Provenience Surface Pattern, In: M. J. O'Brien and D. E. Lewarch (eds.), Plowzone Archaeology: Contributions to Theory and Technique, Vanderbilt University, Nashville, 7-49.

McManamon, F. P. 1984. Discovering Sites Unseen, In: M. B. Schiffer (ed.), Advances in archaeological method and theory, Volume 7, Academic Press, Orlando etc., 223-292.

Medlycott, M. 2017. Archaeological Fieldwalking in Essex, 1986-2005, In: D. Sarlet (ed.), Le projet Planarch 2. Archéologie et amenagement du territoire. Actes du séminaire de clôture, Moulins de Beez-Namur-Belgique, 21-23 novembre 2005, Direction générale de l'Aménagement du territoire, du Logement et du Patrimoine du Ministère de la Région Wallone, Éditions Mardaga, Wavre, 40-47.

Miller, C. L. 1989. Evaluating the Effectiveness of Archaeological Surveys, Ontario Archaeology 49, 3-12.

Novaković, P. 2003. Osvajanje prostora. Razvoj prostorske in krajinske arheologije, Filozofska fakulteta, Ljubljana.

Odell, G. H. and Cowan, F. 1987. Estimating Tillage Effects on Artifact Distributions, American Antiquity 52 (3), 456484.

Ozán, I. L. 2017. Gravity and the formation of the archaeological record: Main concepts and Methodological tools, Geoarchaeology: An International Journal 32 (6), 1-16.

Pawlik, Ł. 2013. The role of trees in the geomorphic system of forested hillslopes - A review, Earth-Science Reviews 126, 250-265.

Peacock, E. and Fant, D. W. 2002. Biomantle Formation and Artifact Translocation in the Upland Sandy Soils: An Example from the Holly Springs National Forest, NorthCentral Mississippi, U.S.A., Geoarchaeology: An International Journal 17 (1- Special Issue: Site Formation Processes in Regional Perspective: Part I), 91-144.
Peet, R. K., Wentworth, T. R. and White, P. S. 1998. A Flexible, Multipurpose Method for Recording Vegetation Composition and Structure, Castanea 63 (3), 262-274.

Plog, S. 1976. Relative Efficiencies of Sampling Techniques for Archaeological Survey, In: K. V. Flannery (ed.), The Early Mesoamerican Village, Academic Press, New York, San Francisco, London, 136-158.

Reynolds, P. 1988. Sherd movement in the ploughzone physical database into computer simulation, In: S. P. Q. Rahtz (ed.), Computer and Quantitative Methods in Archaeology 1988, BAR International Series 446, British Archaeological Reports, Oxford, 201-219.

Schiffer, M. B. 1972. Archaeological Context and Systemic Context, American Antiquity 37 (2), 156-165.

Schaetzl, R. and Anderson, S. 2005. Soils: Genesis and Geomorphology, Cambridge University Press, Cambridge etc.

Schiffer, M. B. 1973. Cultural formation processes of the archaeological record: applications at the Joint site, EastCentral Arizona, PhD Dissertation, University of Arizona (http://hdl.handle.net/10150/288122, Accessed: 27. 10. 2016).

Schiffer, M. B. 1983. Toward the Identification of Formation Processes, American Antiquity 48 (4), 675-706.

Schiffer, M. B., Sullivan, A. P. and Klinger, T. C. 1978. The design of archaeological surveys, World Archaeology 10 (1, Field Techniques and Research Design), 1-28.

Schofield, A. J. 1989. Understanding early medieval pottery distributions: cautionary tales and their implications for further research, Antiquity 63 (240), 460-470.

Shott, M. J. 1987. Feature discovery and the sampling requirements of archaeological evaluations, Journal of Field Archaeology 14 (3), 359-371.

Stafford, C. R. and Creasman, S. D. 2002. The Hidden Record: Late Holocene Landscapes and Settlement Archaeology in the Lower Ohio River Valley, Geoarchaeology: An International Journal 17 (2- Special Issue: Site Formation Processes in Regional Perspective: Part II), 177-140.

Stohlgren, T. J., Falkner, M. B. and Schell, L. D. 1995. A Modified-Whittaker nested vegetation sampling method, Vegetatio 117, 113-121.

Stohlgren, T. J., Chong, G. W., Kalkhan, M. A. and Schell, L. D. 1997. Multiscale Sampling of Plant Diversity: Effects of Minimum Mapping Unit Size, Ecological Applications 7 (3), 1064-1074.

Stohlgren, T. J., Bull, K. A. and Otsuki, Y. 1998. Comparison of rangeland vegetation sampling techniques in the Central Grasslands, Journal of Range Management 51 (2), 164-172.

Sullivan, A. P. 1978. Inference and Evidence in Archaeology: A Discussion of the Conceptual Problems, In: M. B. Schiffer (ed.), Advances in Archaeological Method and 
Theory, Vol. 1, Academic Press, New York, San Francisco, London, 138-222.

Sundstrom, L. 1993. A Simple Mathematical Procedure for Estimating the Adequacy of Site Survey Strategies, Journal of Field Archaeology 20 (1), 91-96.

Terrenato, N. 1996. Field survey methods in Central Italy (Etruria and Umbria), Archaeological Dialogues 3 (2), 216230.

Terrenato, N. 2000. The visibility of sites and the interpretation of field survey results: towards an analysis of incomplete distributions, In: R. Francovich, H. Patterson and G. Barker (eds.), Extracting meaning from ploughsoil assemblages. The Archaeology of the Mediterranean Landscapes 5, Oxbow Books, Oxford, 60-71.

Trachet, J. Delefortrie, S., van Meirvenne, M., Hillewaert, B. and de Clercq, W. 2017. Reassessing Surface Artefact Scatters. The Integration of Artefact-Accurate Fieldwalking with Geophysical Data at Medieval Harbour Sites Near Burges (Belgium), Archaeological Prospection, 24 (2), 101117.

Van Nest, J. 2002. The Good Earthworm: How Natural Processes Preserve Upland Archaic Archaeological Sites of Western Illinois, U.S.A., Geoarchaeology: An International Journal 17 (1-Special Issue: Site Formation Processes in Regional Perspective: Part I), 53-90.
Van de Velde, P. 2001. An extensive alternative to intensive survey: point sampling in the Riu Mannu Survey Project, Sardinia, Journal of Mediterranean Archaeology, 14 (1), 24-52.

Vermeulen, F. and Mlekuž, D. 2012. Surveying an Adriatic Valley: A Wide Area View on Early Urbanization Processes in Northern Picenum, In: F. Vermeulen, G.-J. Burgers, S. Keay and C. Corsi (eds.), Urban Landscape Survey in Italy and the Mediterranean, Oxbow Books, Oxford, 207-222.

Wandsnider, L. and Camilli, E. L. 1992. The Character of Surface Archaeological Deposits and Its Influence on Survey Accuracy, Journal of Field Archaeology 19 (2), 169-188. Wessel, I. and Wohlfarth, C. 2008. Archäologische Forschungen auf der Rheinbacher Lößplatte. Ein Projekt zur Prospektion in einem geographischen Kleinraum, LVRAmt für Bodenkmalpflege im Rheinland, Verlag Philipp von Zabern, Mainz am Rhein.

Yorston, R. M., Gaffney, V. L. and Reynolds, P. J. 1990. Simulation of Artefact Movement Due to Cultivation, Journal of Archaeological Science 17 (1), 67-83. 